Article

\title{
Phenylpyrazalopyrimidines as Tyrosine Kinase Inhibitors: Synthesis, Antiproliferative Activity, and Molecular Simulations
}

\author{
Bhupender S. Chhikara ${ }^{1,2}$, Sajda Ashraf ${ }^{3}$, Saghar Mozaffari ${ }^{4}$, Nicole St. Jeans ${ }^{2}$, \\ Dindyal Mandal ${ }^{2,4}$, Rakesh Kumar Tiwari ${ }^{2,4}{ }^{(D)}$, Zaheer Ul-Haq ${ }^{3, *(D)}$ and \\ Keykavous Parang 2,4,*(D)
}

1 Department of Chemistry, Aditi Mahavidyalaya, University of Delhi, Bawana, Delhi 110039, India; bschhikara@gmail.com

2 Department of Biomedical and Pharmaceutical Sciences, College of Pharmacy, University of Rhode Island, Rhode Island, Kingston, RI 02881, USA; nicolestjean@ymail.com (N.S.J.); mandal@chapman.edu (D.M.); tiwari@chapman.edu (R.K.T.)

3 Dr. Panjwani Center for Molecular Medicine and Drug Research, ICCBS, University of Karachi, Karachi 75210, Pakistan; sajda.ashraf@yahoo.com

4 Center For Targeted Drug Delivery, Department of Biomedical and Pharmaceutical Sciences, Chapman University School of Pharmacy, Harry and Diane Rinker Health Science Campus, California, Irvine, CA 92618, USA; mozaf100@mail.chapman.edu

* Correspondence: zaheer.qasmi@iccs.edu (Z.U.-H.); parang@chapman.edu (K.P.); Tel.: +92-321-9255-322 (Z.U.-H.); +1-714-516-5489 (K.P.);

Fax: +92-21-99261713 (Z.U.-H.); +1-714-516-5481 (K.P.)

Academic Editor: Qiao-Hong Chen

Received: 15 April 2020; Accepted: 29 April 2020; Published: 2 May 2020

\begin{abstract}
N1-( $\alpha, \beta$-Alkene)-substituted phenylpyrazolopyrimidine derivatives with acetyl and functionalized phenyl groups at $\alpha$ - and $\beta$-positions, respectively, were synthesized by the reaction of 3-phenylpyrazolopyrimidine (PhPP) with bromoacetone, followed by a chalcone reaction with differently substituted aromatic aldehydes. The Src kinase enzyme assay revealed modest inhibitory activity (half maximal inhibitory concentration, $\mathrm{IC}_{50}=21.7-192.1 \mu \mathrm{M}$ ) by a number of PhPP derivatives. Antiproliferative activity of the compounds was evaluated on human leukemia (CCRF-CEM), human ovarian adenocarcinoma (SK-OV-3), breast carcinoma (MDA-MB-231), and colon adenocarcinoma (HT-29) cells in vitro. 4-Chlorophenyl carbo-enyl substituted 3-phenylpyrazolopyrimidine (10) inhibited the cell proliferation of HT-29 and SK-OV-3 by $90 \%$ and $79 \%$, respectively, at a concentration of $50 \mu \mathrm{M}$ after $96 \mathrm{~h}$ incubation. The compound showed modest inhibitory activity against c-Src $\left(\mathrm{IC}_{50}\right.$ $=60.4 \mu \mathrm{M})$, Btk $\left(\mathrm{IC}_{50}=90.5 \mu \mathrm{M}\right)$, and Lck $\left(\mathrm{IC}_{50}=110 \mu \mathrm{M}\right)$, while it showed no activity against Abl1, Akt1, Alk, Braf, Cdk2, and PKCa. In combination with target selection and kinase profiling assay, extensive theoretical studies were carried out to explore the selectivity behavior of compound 10. Specific interactions were also explored by examining the changing trends of interactions of tyrosine kinases with the phenylpyrazolopyrimidine derivative. The results showed good agreement with the experimental selectivity pattern among c-Src, Btk, and Lck.
\end{abstract}

Keywords: protein kinase; phenylpyrazolopyrimidine; antiproliferative activity; enzyme inhibition; molecular simulation

\section{Introduction}

Cancer cells show the overexpression of different protein tyrosine kinases (PTKs). These enzymes catalyze the phosphorylation of many protein substrates by the transfer of the $\gamma$-phosphate group from ATP to specific tyrosine residues. PTKs have critical roles in signal transduction pathways. 
Src family kinases (SFKs) have nine different PTKs, including c-Src, c-Yes, Fyn, Lck, Lyn, Hck, Frk, Blk, and c-Fgr of which Src is the prototype [1]. SFKs have essential roles in the regulation of a wide variety of normal cellular signal transduction pathways, such as cell division, differentiation, growth factor signaling, survival, adhesion, migration, and invasion [2]. Src tyrosine kinase expression is frequently elevated in several tumors, including breast, colon, prostate, lung, ovary, and pancreas, when it is compared with the adjacent healthy tissues. Src kinase was shown to be the critical modulator of cancer cell metastasis and invasion [3].

In recent years, a number of small cell-permeable inhibitors of protein kinases were investigated for the treatment of different cancers [4]. Different small molecules that were actively investigated as kinase inhibitor include quinazolines [5], quinolinecarbonitriles [6], pyrazolopyrimidines [7,8], imidazo [1,5-a]pyrazines [9], Calixarene [10], benzotriazines [11,12], indoles [13], and ATP- phosphopeptide conjugates [14]. The research effort led to the generation of small molecules for the treatment of different malignancies. Imatinib, a 2-phenylaminopyrimidine, was approved for the treatment of chronic myelogenous leukemia (CML) and gastrointestinal stromal tumors (GISTs) [15]. Dasatinib (BMS-354825), a pyrimidinylthiazole derivative, was approved to use in patients with CML after imatinib treatment [16], and bosutinib (SKI-606), a 3-quinolinecarbonitrile analogue, is known to suppress migration and invasion of human breast cancer cells [17]. Ibrutinib (Figure 1) is a pyrazolopyrimidine-based [18] small-molecule kinase inhibitor that was approved for the treatment of B-cell cancers like mantle cell lymphoma, chronic lymphocytic leukemia, and Waldenström's macroglobulinemia $[19,20]$.
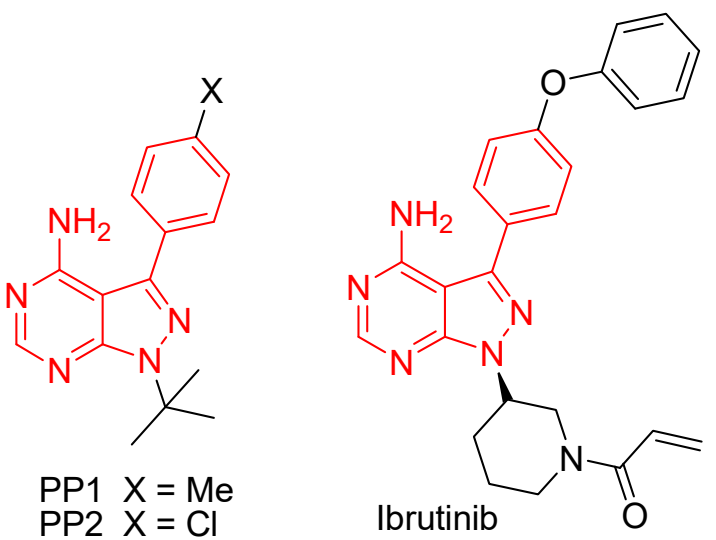

Figure 1. Chemical structures of 3-phenylpyrazolopyrimidine (PhPP) derivatives (PP1 and PP2) and Ibrutinib.

A number of crystallographic studies showed that adenosine $5^{\prime}$-( $\beta, \gamma$-imido)triphosphate (AMP-PNP), an ATP mimic, binds to the ATP-binding site of c-Src (Protein Data Bank (PDB) 2SRC) [21]. Furthermore, complexes of 3-phenylpyrazolopyrimidine (PhPP) derivatives (PP1 and PP2) (Figure 1) act as ATP-binding site inhibitors of Hck (PDB 1QCF) and Lck (PDB 1QPE) [22]. Indeed, the pyrazolopyrimidine core of PP1 and PP2 (Figure 1) mimics the adenine base of ATP in binding to the nucleotide-binding site. In another study [8], we showed that the 3-phenyl group interacts with a large hydrophobic pocket in the ATP-binding site, contributing significantly to Src kinase inhibitory activity. There is also another cavity formed from side chains of helix $\alpha \mathrm{C}$ and helix $\alpha \mathrm{D}$ that is normally occupied by a carbohydrate moiety followed by a triphosphate group of ATP. This cavity is mostly unfilled by the tert-butyl of 3-phenylpyrazolopyrimidines (PP1 and PP2). Furthermore, we investigated the variation of $N 1$ substitution in 3-phenylpyrazolopyrimidines with different 1,2,3-triazoles containing hydrophobic residues to interact with amino acids of this cavity and contribute to the enhancement of Src kinase inhibitory potency [8]. The cysteine residue present in the cavity could be a potential target to bind with PhPP molecules irreversibly, leading to a potential increase in kinase inhibition. 
Here, we describe the synthesis and evaluation of kinase inhibitory activity of N1-substituted PhPP with $\alpha$-acetyl- $\beta$-phenyl-alkene groups (Figure 2). We hypothesized that this substitution at the $N 1$ position of PhPP could contribute significantly to the kinase inhibition through generating specific interactions. We further extended our study to investigate the selectivity profile of one of the active compounds (10) with a panel of nine different kinases by applying MD and MMGBSA calculations. This study helped to reveal the inhibitory mechanism of PhPP derivatives based on their distinct structural characteristics required for its interaction with a specific kinase.<smiles>CC(=O)Cn1nc(-c2ccccc2)c2c(N)ncnc21</smiles>

2<smiles>COc1ccc(/C=C(\C(C)=O)n2nc(-c3ccccc3)c3c(N)ncnc32)cc1</smiles><smiles>CC(=O)/C(=C\c1ccc(Cl)cc1)n1nc(-c2ccccc2)c2c(N)ncnc21</smiles><smiles>CC(=O)/C(=C\c1ccc(C)cc1)n1nc(-c2ccccc2)c2c(N)ncnc21</smiles><smiles>CC(=O)/C(=C\c1ccc(N(C)C)cc1)n1nc(-c2ccccc2)c2c(N)ncnc21</smiles><smiles>CC(=O)/C(=C\c1ccccc1)n1nc(-c2ccccc2)c2c(N)ncnc21</smiles>

14<smiles>CC(=O)/C(=C\c1ccc(F)cc1)n1nc(-c2ccccc2)c2c(N)ncnc21</smiles><smiles>CC(=O)/C(=C\c1ccc(Cl)cc1Cl)n1nc(-c2ccccc2)c2c(N)ncnc21</smiles><smiles>c1ccc(C2(CC3CCCC3)CC2)cc1</smiles><smiles>C/C=C(\C(C)=O)n1nc(-c2ccccc2)c2c(N)ncnc21</smiles>

8<smiles>CC(=O)/C(=C\c1ccccc1Cl)n1nc(-c2ccccc2)c2c(N)ncnc21</smiles><smiles>CC(=O)/C(=C\c1cccc(C)c1)n1nc(-c2ccccc2)c2c(N)ncnc21</smiles><smiles>CC(=O)/C(=C\c1ccc(-c2ccccc2)cc1)n1nc(-c2ccccc2)c2c(N)ncnc21</smiles><smiles>CC(=O)/C(=C\c1cccc([N+](=O)[O-])c1)n1nc(-c2ccccc2)c2c(N)ncnc21</smiles><smiles>CC(=O)/C(=C\c1ccccc1F)n1nc(-c2ccccc2)c2c(N)ncnc21</smiles>

Figure 2. Chemical structures of N1-substituted PhPP with $\alpha$-acetyl- $\beta$-phenyl-alkene groups ( $E$ and $\mathrm{Z}$ isomers). 


\section{Results and Discussion}

\subsection{Chemical Synthesis}

The products were synthesized by following the chemical pathway shown in Scheme 1 . The PhPP (1) was synthesized according to a reported procedure [23]. The N1 of 1 was substituted with bromoacetone in the presence of potassium carbonate as a base. Product 2 was confirmed by NMR, which showed the disappearance of the proton peak of $\mathrm{NH}$ at $8.07 \mathrm{ppm}$ of $\mathbf{1}$ and appearance of the peak at $5.24 \mathrm{ppm}$ and $2.21 \mathrm{ppm}$ for $\mathrm{CH}_{2}$ and $\mathrm{CH}_{3}$, respectively, in ${ }^{1} \mathrm{H}$ NMR. Furthermore, ${ }^{13} \mathrm{C}$ NMR showed peaks at 201.34 ppm, 56.15 ppm, and 27.14 ppm representing the carbonyl group, $\mathrm{CH}_{2}$, and $\mathrm{CH}_{3}$, respectively, in product 2 .

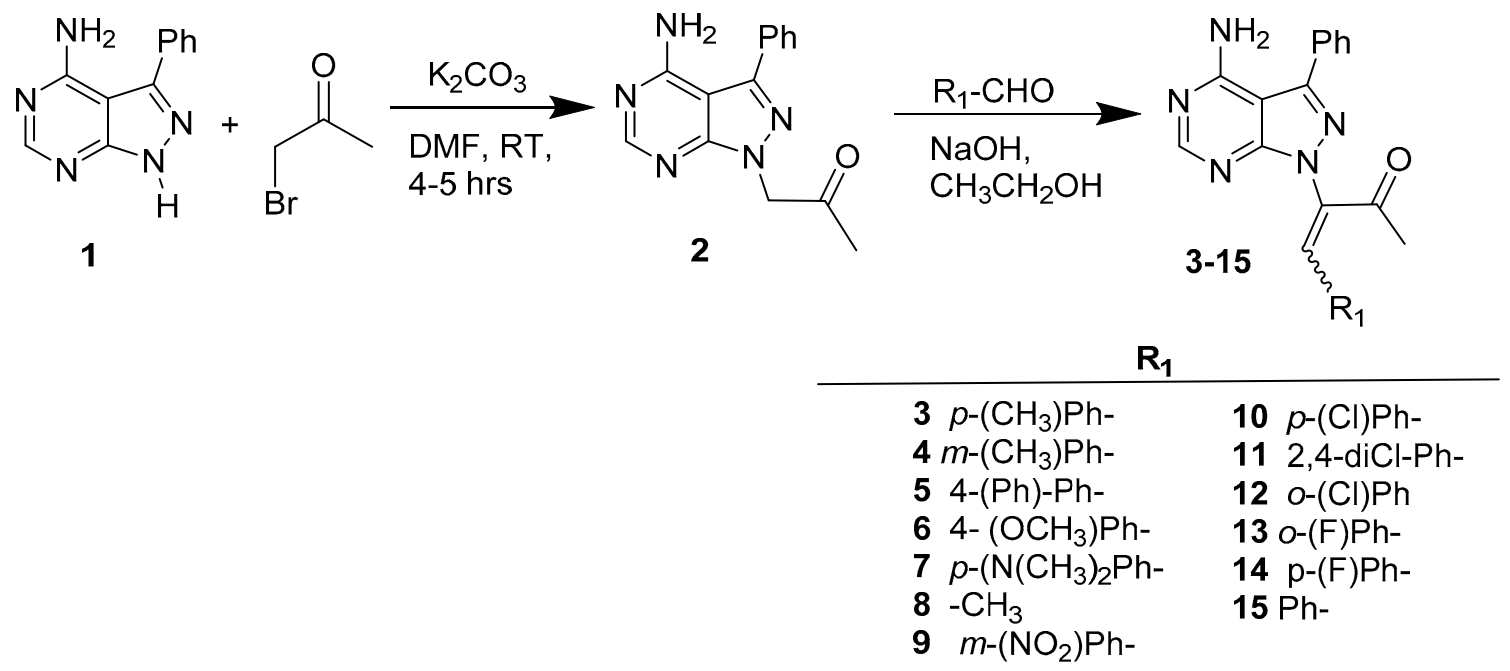

Scheme 1. Chemical synthesis of PhPP derivatives.

Next, the double bond group was introduced by the chalcone reaction. The anion of 2 generated by sodium hydroxide was reacted with different benzaldehydes at room temperature to give product 3. The ratio of starting material and amount of solvent defined the formation of product and side products. A higher concentration (i.e., less amount of solvent ethanol) and the presence of higher equivalents of $\mathbf{2}$ than the aldehyde lead to a second internal Michael reaction where the anion of $\mathbf{2}$ reacts with product 3 , leading to the formation of side product as indicated by Electrospray Ionization Mass Spectrometry (ESI-MS) at 659 Da (data not shown). In an optimum condition, the aldehyde and reactant 2 should be present in more than 1.4:1 equivalent, and solvent ethanol should be present in approximately $20 \mathrm{~mL}$ for $26 \mathrm{mg}(0.1 \mathrm{mmol})$ of 2 . Out of two possible products after the conjugation of 2 with 4-methylbenzaldehyde, only product 3 was observed, suggesting the reaction of the carbanion of methylene $\left(\mathrm{CH}_{2}\right)$ group between the carbonyl and nitrogen rather than that of methyl $\left(\mathrm{CH}_{3}\right)$. The formation of product 3 was confirmed by ESI-MS by the presence of a mass peak at $370 \mathrm{Da}[\mathrm{M}+$ $\mathrm{H}]^{+}$. This was confirmed by ${ }^{1} \mathrm{H}$ NMR, which showed the absence of a peak at $5.24 \mathrm{ppm}$ for $\mathrm{CH}_{2}$ of $\mathbf{2}$, while the three protons for $\mathrm{CH}_{3}$ were present at $2.31 \mathrm{ppm}$. Correspondingly, in ${ }^{13} \mathrm{C} \mathrm{NMR}$, the peak at 56.15 ppm (assigned to $\mathrm{CH}_{2}$ ) was absent in 3 while the peak at $26.13 \mathrm{ppm}$ (assigned to $\mathrm{CH}_{3}$ with slight upfield shift) was present. Furthermore, out of EZ possible isomers for the double bond, both the isomers were present as indicated by NOE NMR spectra, possibly by rotation introduced due to keto-enol tautomerism.

In the case of product 8 , the chalcone reaction was carried with precaution to avoid the formation of side products due to the presence of $\alpha$-hydrogen in acetaldehyde. The anion of $\mathbf{2}$ was generated first with 1.1 equivalent of sodium hydroxide over extended time and added to the solution of acetaldehyde (1.2 equivalents). The reaction was quenched with acetic acid after $30 \mathrm{~min}$. The product was confirmed by ESI-MS and NMR. The products were purified by HPLC and showed a purity of 95-99\%. 


\subsection{Src-Kinase Assay}

In vitro Src kinase assay for some of the compounds was conducted, as presented in Table 1. As results indicated, the compounds were moderately active against the Src kinase. Among all the tested compounds, compounds 6 and 4 were found to be the most potent with $\mathrm{IC}_{50}$ values of 21.7 and $24.7 \mu \mathrm{M}$, respectively. Compounds 3 and 7 exhibited $\mathrm{IC}_{50}$ values of $32.9 \mu \mathrm{M}$ and 36.8 , respectively. Compound 5 showed the lowest activity with an $\mathrm{IC}_{50}$ of $192.1 \mu \mathrm{M}$. Since the compounds showed only moderate Src kinase inhibitory activity, they were evaluated for antiproliferative activity first to find the lead compound for further kinase inhibitory assays.

Table 1. In vitro Src kinase inhibition assay for the selected compounds.

\begin{tabular}{cc}
\hline Compound No. & IC $_{\mathbf{5 0}}(\boldsymbol{\mu M})^{\mathbf{a}}$ \\
\hline $\mathbf{3}$ & 32.9 \\
$\mathbf{4}$ & 24.7 \\
$\mathbf{5}$ & 192.1 \\
$\mathbf{6}$ & 21.7 \\
$\mathbf{7}$ & 36.9 \\
Staurosporine & 0.6 \\
PP2 & 0.5
\end{tabular}

a All experiments were repeated in triplicate. All the standard deviations were in the range of $6-13 \%$.

\subsection{Antiproliferative Activities}

The effect of compounds on the cell proliferation of cancer cells was evaluated in vitro in a human leukemia cell line (CCRF-CEM) according to the previously reported procedures [24,25], breast adenocarcinoma (MDA-MB-231), ovarian adenocarcinoma (SK-OV-3), and colon adenocarcinoma (HT-29) cell lines up to $72 \mathrm{~h}$. Doxorubicin (Dox) was used as a positive control as shown previously [26-29]. These cell lines were selected to determine the antiproliferative activity against diverse cancer cells. Compounds 10 and 11 consistently inhibited the cell proliferation 72-96 h in all cell lines. The percentage of cell proliferation was significantly reduced in HT-29 cells in the presence of $\mathbf{1 0}$ and $\mathbf{1 1}$ when compared with Dox and other compounds. Compound 10 was more effective in the order of HT-29 (90\%) > CCRF-CEM, SK-OV-3 (79\%) > MDA-MB-231 (60\%), while Dox showed HT-29 (75\%) > CCRF-CEM, SK-OV-3 (73\%) > MDM-MB-231 (64\%) after $96 \mathrm{~h}$. Compounds 2, 7, 9, and 12 were found to be inactive in reducing the cell proliferation in all the cell lines after 24-96 h while other compounds 3 and 13-15 exhibited comparable or slightly less antiproliferative activity (Figure 3A-D) than compounds 10 and 11 after $96 \mathrm{~h}$. These data indicate that the presence of the chlorine group at the para position in compounds $\mathbf{1 0}$ and $\mathbf{1 1}$ were effective in improving the antiproliferative activities. However, the absence of phenyl and/or double bonds in compounds 2 and 8 significantly reduced the antiproliferative activities versus 10 and 11. The presence of $p$-dimethylamino, $m$-nitro, and $o$-chlorine in 7, 9, and 12 were not productive while $o$-fluorine (13), $p$-fluorine (14), unsubstituted phenyl (15), and $p$ - $\mathrm{Cl}(\mathbf{1 0}$ and 11) enhanced the antiproliferative activity. Compounds 5 and 6 with $p$-ph and $p$-methoxy exhibited antiproliferative activity against some of the cell lines, with 5 being more active in HT-29 and 6 in CCRF-CEM and SK-OV3 cells. However, their activity was generally less than compounds 3, 10, 11, 13, and 14. Compounds 10 and 11 exhibited $\mathrm{IC}_{50}$ values of $25.5 \mu \mathrm{M}$ and $34.3 \mu \mathrm{M}$, respectively, after $72 \mathrm{~h}$ incubation against SK-OV-3 cells (Figure 4). 


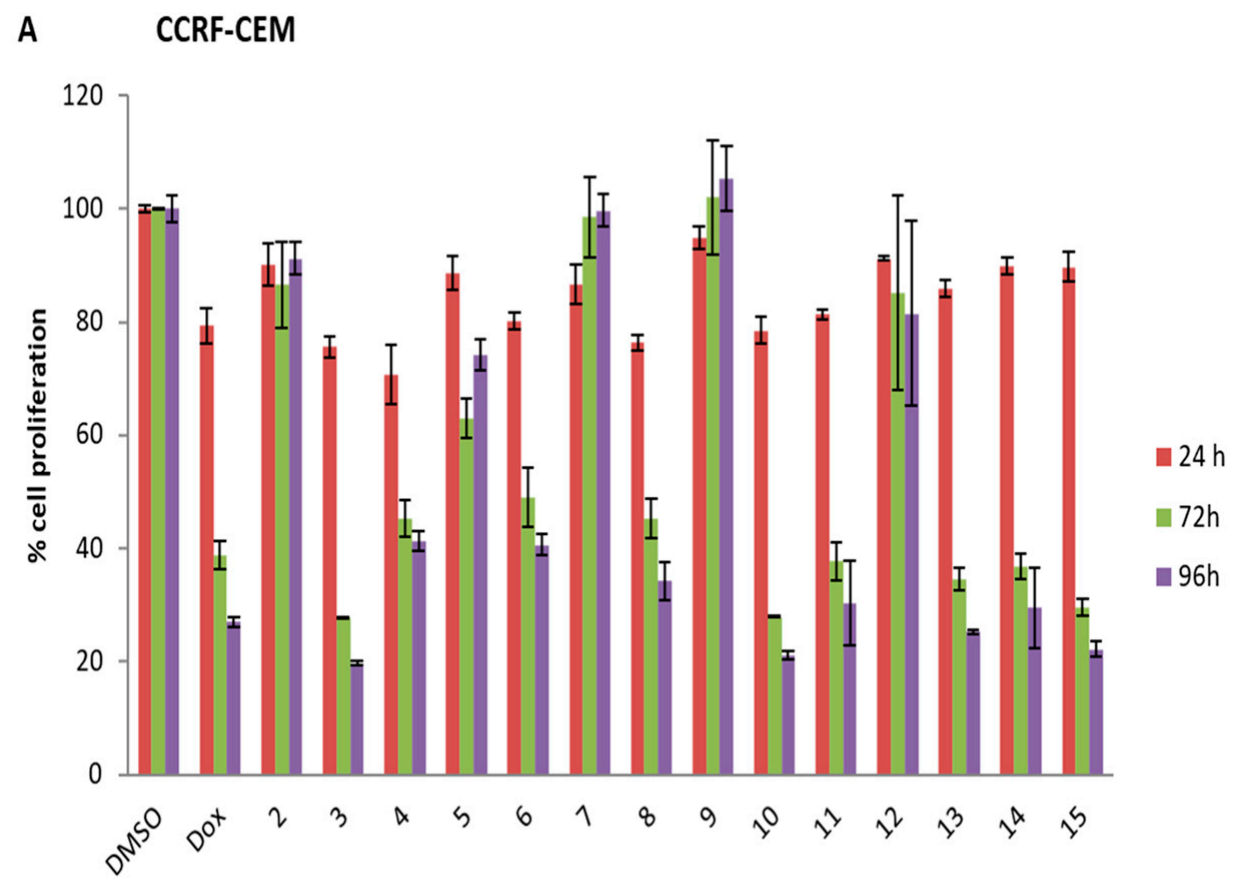

Compound No.

B

SK-OV-03

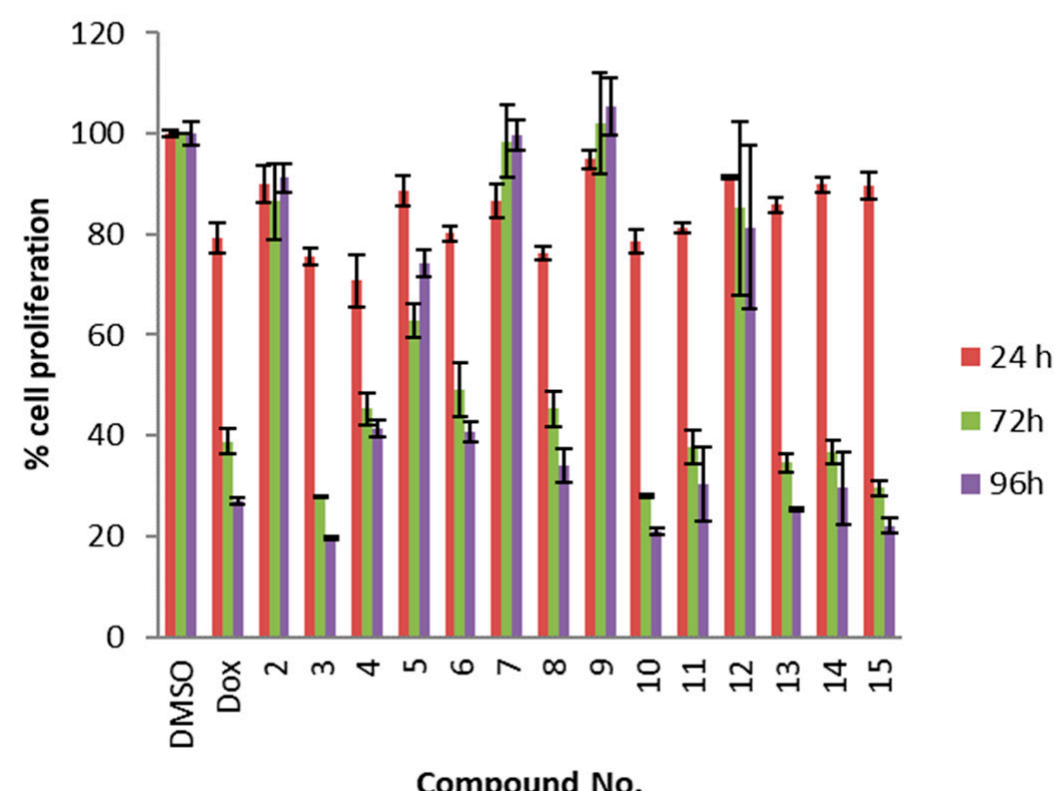

Figure 3. Cont. 
C HT-29

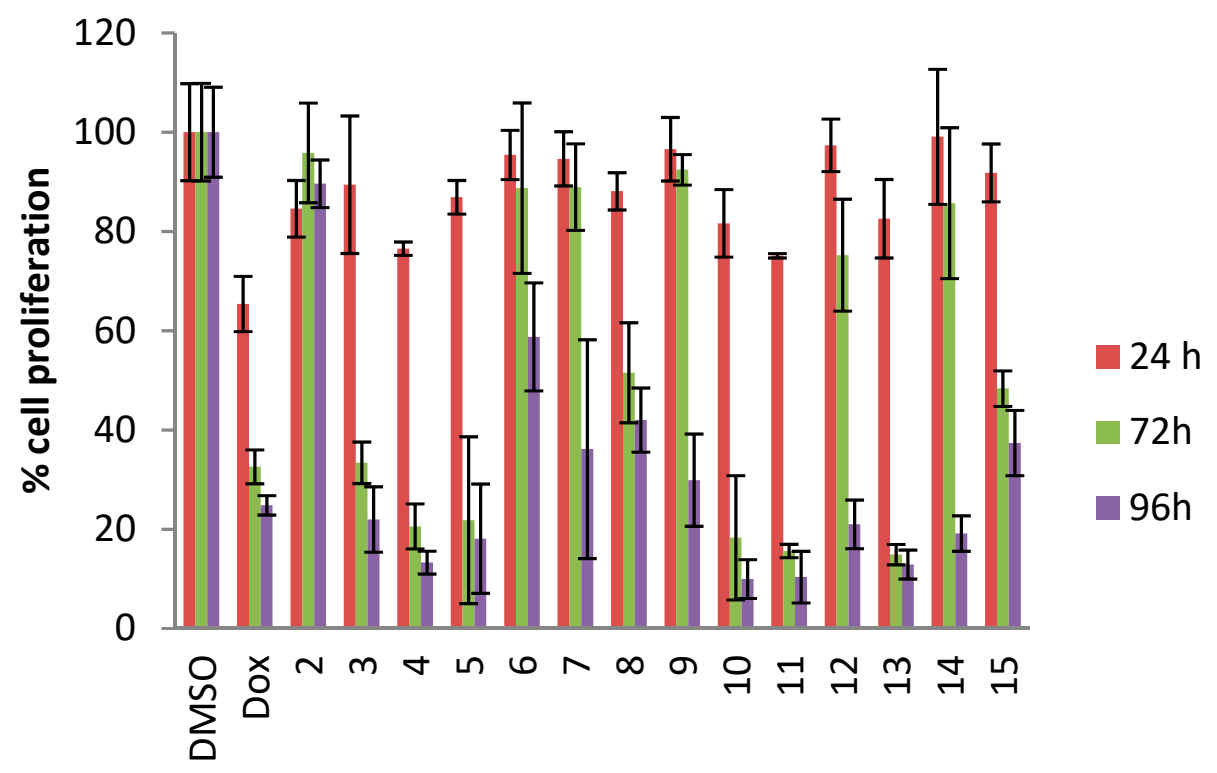

Compound No.

D MDA-MB-231

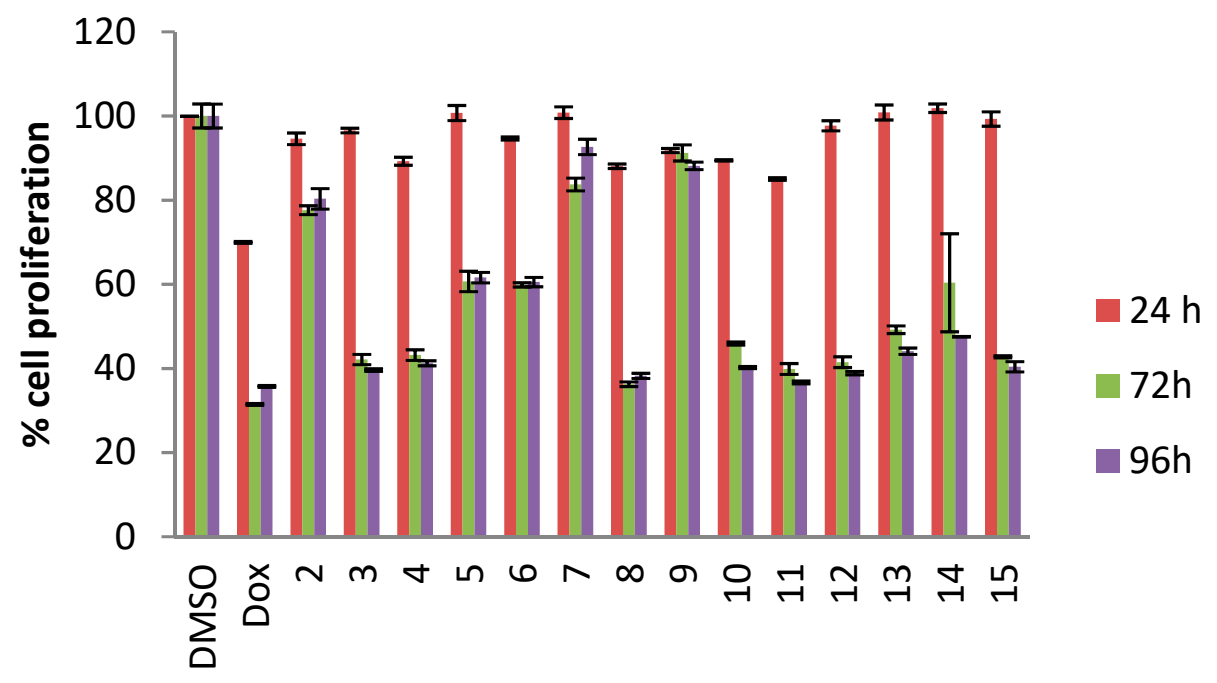

Compound No.

Figure 3. Antiproliferative activity of PhPP derivatives $(50 \mu \mathrm{M})$ and doxorubicin (Dox) $(1 \mu \mathrm{M})$ against CCRF-CEM (A), SK-OV-3 (B), HT-29 (C), and MDA-MB-231 (D) cell lines. All experiments were repeated in triplicate. 

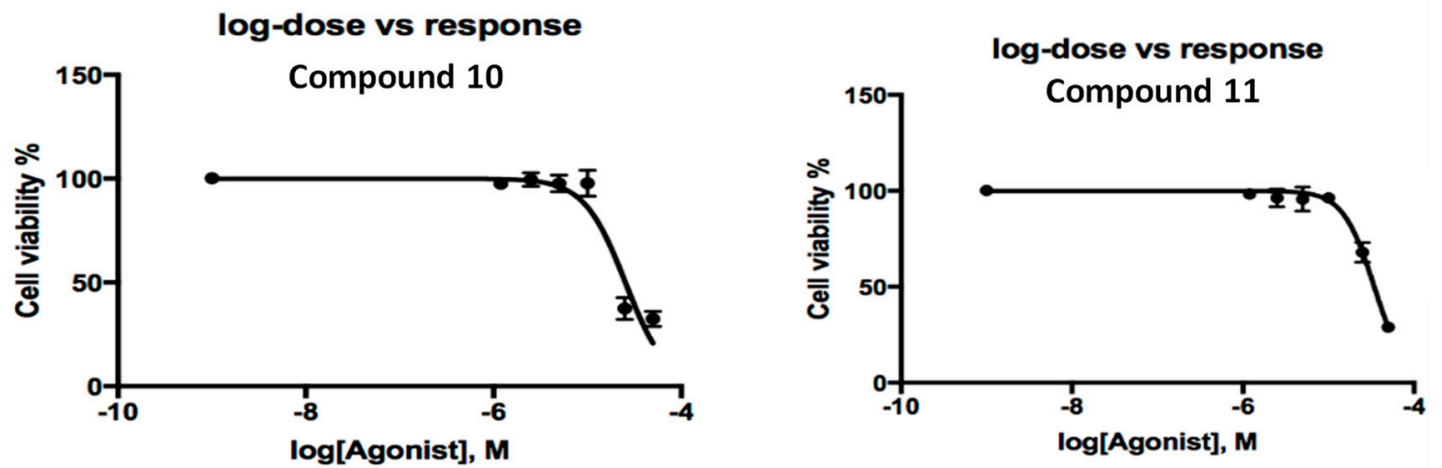

Figure 4. Dose-response curves of 10 (left) and 11 (right) after $72 \mathrm{~h}$ incubation against SK-OV-3 cells.

Compound 10 was selected for further evaluation against a panel of kinases to determine the mechanism of activity. The results are shown in Table 2 against Abl1, Akt1, Alk, Braf, Btk, Cdk2, cSrc, Lck, and PKCa enzymes. The data indicate modest activity against Btk, c-Src, and Lck while the compound was inactive or showed very low inhibition activity against other kinases.

Table 2. The activity of compound 10 against a panel of protein kinases.

\begin{tabular}{ccc}
\hline Kinase & $\begin{array}{c}\text { Compound 10 } \\
\text { IC }_{50}(\mu \mathrm{M})\end{array}$ & Control Compound $\mathrm{IC}_{\mathbf{5 0}}(\boldsymbol{M M})$ \\
\hline Abl1 & $\mathrm{NA}^{\mathrm{a}}$ & $0.85^{\mathrm{b}}$ \\
Akt1 & $>150$ & $0.012^{\mathrm{b}}$ \\
Alk & $\mathrm{NA}$ & $0.01^{\mathrm{b}}$ \\
Braf & $\mathrm{NA}$ & $0.018^{\mathrm{c}}$ \\
Btk & 95.4 & $0.067^{\mathrm{b}}$ \\
Cdk2/Cyclin A1 & $\mathrm{NA}$ & $0.0039^{\mathrm{b}}$ \\
c-Src & 64.1 & $0.0085^{\mathrm{b}}$ \\
Lck & 110 & $0.011^{\mathrm{b}}$ \\
PKCa & NA & $0.0016^{\mathrm{b}}$
\end{tabular}

a Not active (NA) indicates no inhibition or compound activity that could not be fit to an $\mathrm{IC}_{50}$ curve; $^{\mathrm{b}}$ Staurosporine; ${ }^{c}$ GW5074.

\subsection{Molecular Modeling}

To rationalize the activity of compound 10, KEGG pathway and molecular dynamics simulation studies were utilized to explore the specific behavior of the $Z$ configuration compound 10 against multiple kinases.

\subsubsection{Target Identification}

Conventional identification of drug targets is an expensive, time-consuming, and difficult process; only a few drug targets can be identified. In contrast, the computational method permits a great deal of analysis within a short period and brings a large number of potential drug targets from a pool of information [30]. In the present study, an integrated in silico approach was used to identify potential targets [31] for the active compound 10. Initially, the disease search tool in the KEGG database was used against breast, ovarian, and colorectal cancer to extract the targets that may be involved in these diseases (Figures 5-7) [32]. KEGG uses the knowledge of gene function and linking this information with advanced order functional information by using systematic analysis. The schematic presentation of the KEGG pathway shows genes marked as light-blue color as a drug target and genes marked as pink as associated with the disease, whereas when the gene is linked with both a disease and a drug target, its color is split into light blue and pink. There were several target proteins involved in one pathway; therefore, protein-drug association servers Similarity Ensemble Approach (SEA, http://sea.bkslab.org/) [33], Search Tool for the Retrieval of Interacting Genes (STRING, 
http://string-db.org) [34], and Search Tool for Interacting Chemicals (STITCH, http://stitch.embl.de/) [35] were used. The STRING database was used to explain the molecular function, biological processes, cellular components, and pathways of the target proteins. The SEA relates target proteins based on set-wise chemical similarity among their compounds. A total of 14 potential targets (Btk, Itk, c-Src, EGFR, Akt1, Fyn, Lyn, Lck, PKC, Abl1, Hck, Cdk2, Braf, and Her2) were selected based on the data obtained from these servers that further proved the reliability of text mining and molecular docking.

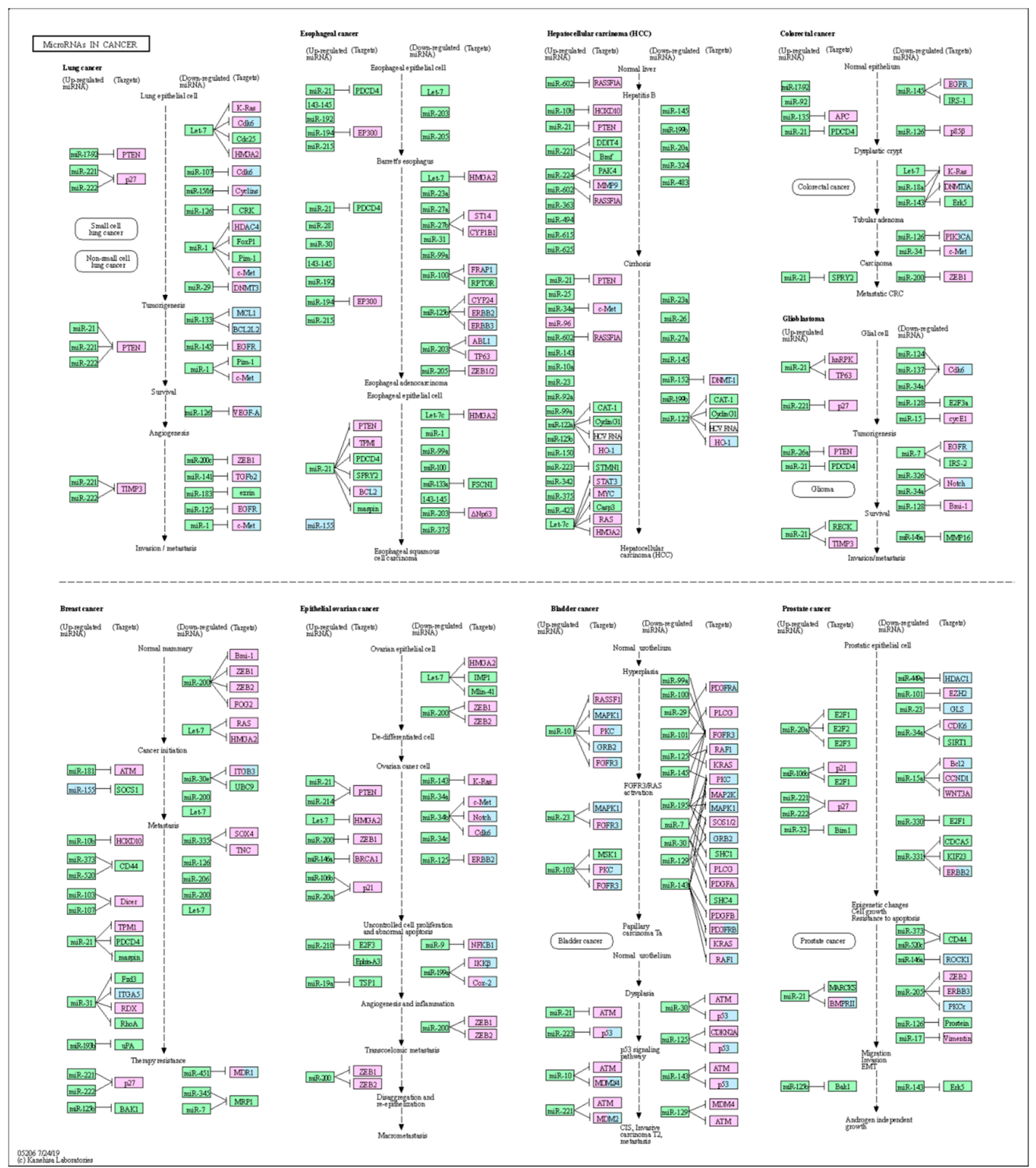

Figure 5. The KEGG pathway for ovarian cancer. 


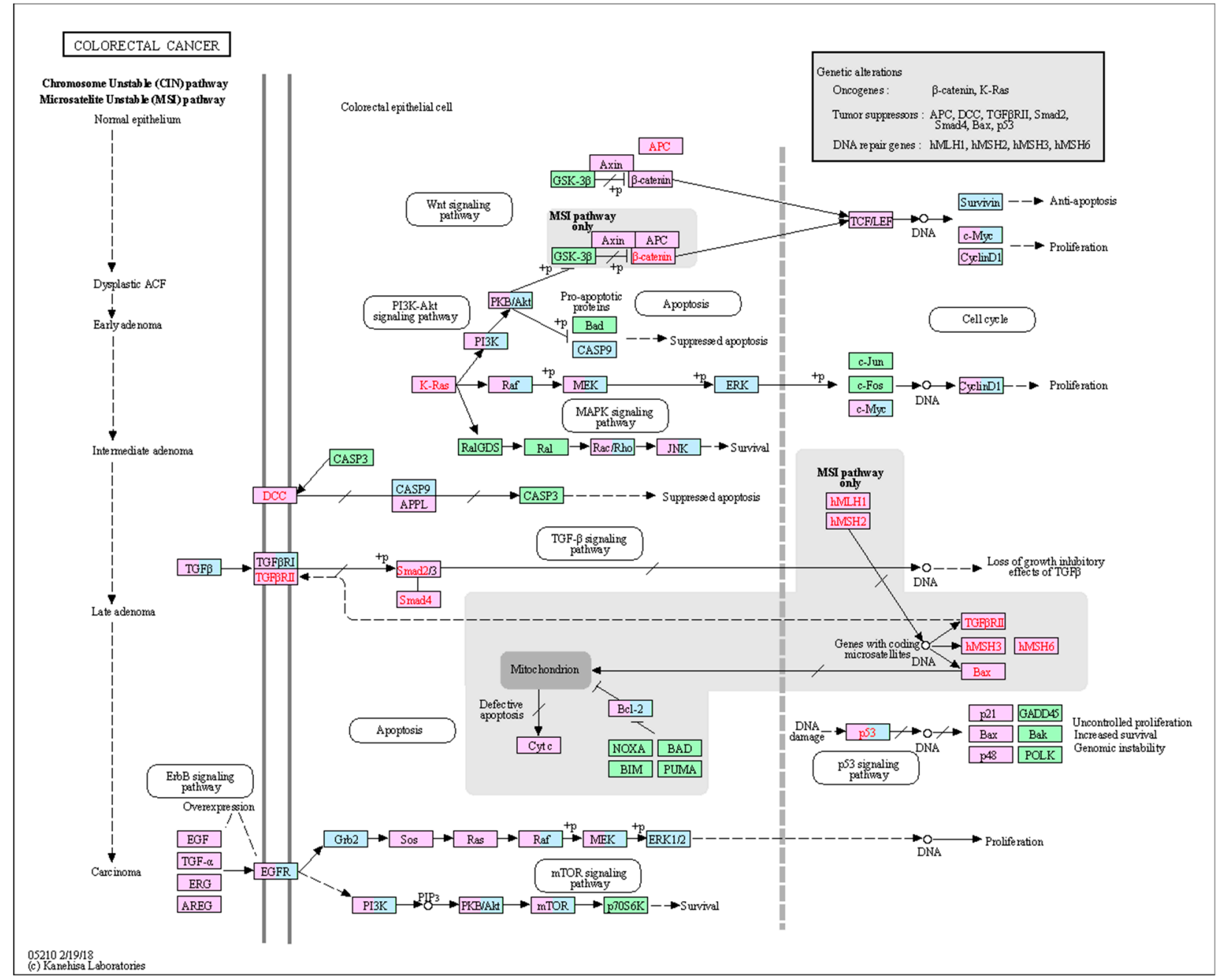

Figure 6. The KEGG pathway for colorectal cancer. 


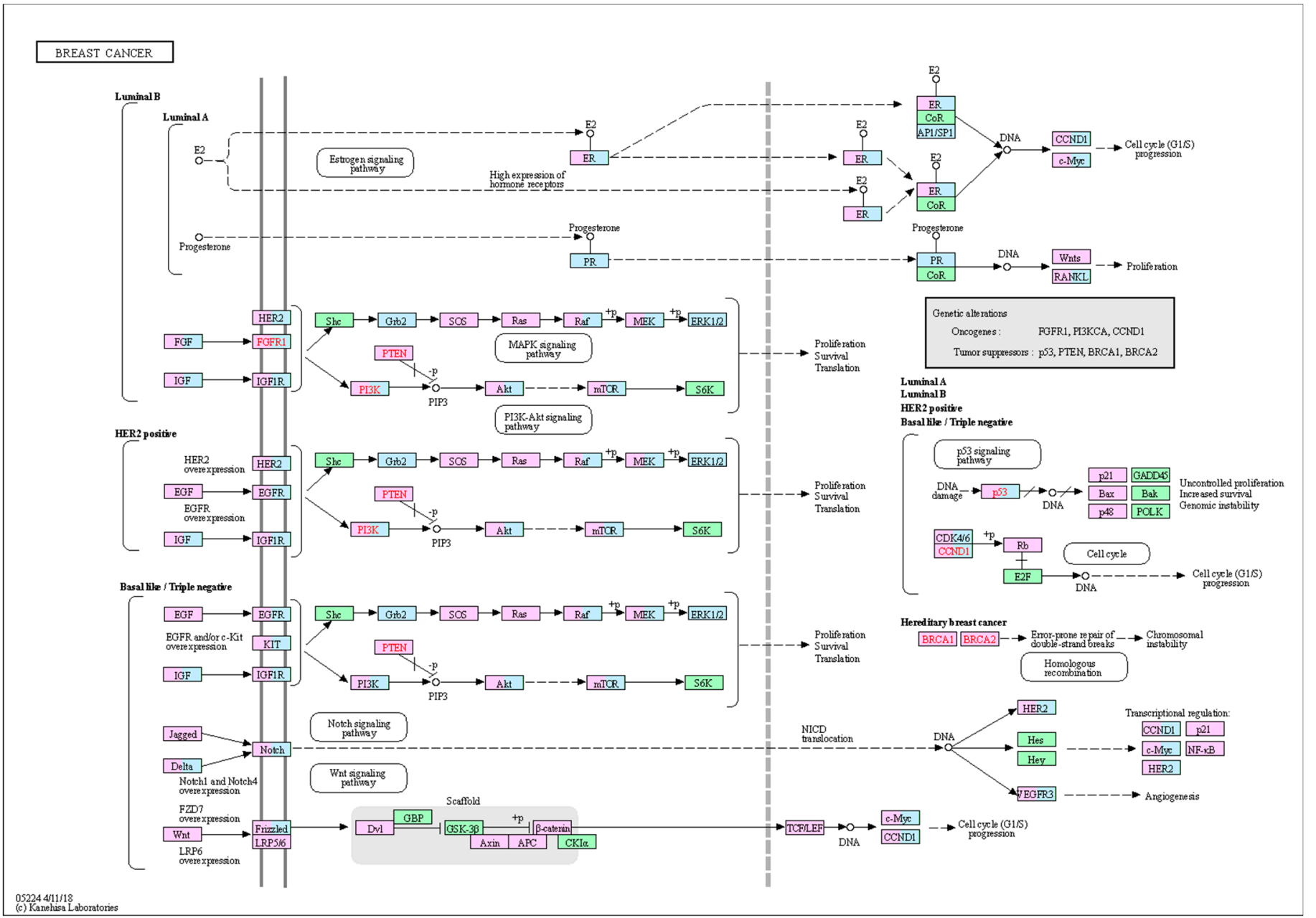

Figure 7. The KEGG pathway for breast cancer. 


\subsubsection{Docking Studies}

The known compounds that were already reported as inhibitors of the target proteins, as well as nature and crucial active site residues, were specified in their accessible complexes, used as a positive control. Prior to docking, validation of the software and docking conditions was performed by retrieving the control compounds from their crystal complexes and then redocking by MOE against their relevant targets. The redocking results are presented in Table 3. After validation, docking of compound 10 was performed with all 14 targets, and their docking scores were compared with the control in order to select a target with the highest docking score. We observed that compound $\mathbf{1 0}$ presented good scores against Btk, Itk, c-Src, EGFR, Akt1, Fyn, Lyn, Lck, PKC, and Abl1 kinase as compared to Hck, Cdk2, Braf, and Her2. The docking scores of compound $\mathbf{1 0}$ are presented in Table 4.

Table 3. Predicted binding affinity (docking scores in $\mathrm{kcal} / \mathrm{mol}$ ) and root-mean-square deviation (RMSD) of control inhibitors against related proteins.

\begin{tabular}{ccc}
\hline Target Proteins & Docking Score of Comp. 10 & RMSD (̊) \\
\hline c-Src & -8.3240 & 1.5 \\
Btk & -7.6201 & 0.75 \\
Itk & -8.1748 & 1.4 \\
EGFR & -7.7890 & 1.56 \\
Fyn & -7.5002 & 1.32 \\
Lyn & -5.9252 & 1.23 \\
Hck & -5.1107 & 0.9 \\
Her2 & -8.7522 & 0.54 \\
Lck & -7.7834 & 0.45 \\
PKC & -6.4224 & 0.82 \\
Braf & -6.8762 & 1.52 \\
Abl1 & -6.7421 & 0.85 \\
Akt1 & -7.8654 & 0.74 \\
Cdk2 & -5.2409 & 0.95 \\
\hline
\end{tabular}

Table 4. MM/PBSA derived binding free energies of complexes computed from the MD simulations.

\begin{tabular}{cccccccccc}
\hline & c-Src & PKC & Akt & Alk & Btk & CDK2 & Lck & Abl1 & Braf \\
\hline VDWAALS & -40.343 & -46.197 & -35.635 & -35.533 & -46.946 & -50.067 & -34.248 & -40.962 & -31.802 \\
EEL & -13.296 & -19.577 & -15.181 & -3.935 & -13.128 & -29.554 & -15.558 & -18.300 & -10.603 \\
EPB/EGB & 32.183 & 39.385 & 33.442 & 23.836 & 36.678 & 54.064 & 32.371 & 39.952 & 26.077 \\
ESURF/ECAVITY/ & -5.024 & -5.873 & -3.961 & -4.54 & -5.820 & -6.421 & -4.623 & -5.313 & -4.283 \\
$\quad \begin{array}{c}\text { ENPOLAR } \\
\text { DELTA G }\end{array}$ & -20.633 & -21.653 & -15.645 & -5.210 & -15.683 & -6.893 & -18.093 & -9.629 & -20.433 \\
binding (PB) & & & & & & & & &
\end{tabular}

\subsubsection{Structure Architecture of Kinases}

The structure of all protein kinase domains is composed of a small, typically $\beta$-stranded $N$-lobe linked with a small hinge region to a bigger $\alpha$-helical $C$-lobe. In protein kinases, ATP binds to the cavity that lies between $N$ - and C-terminal lobes creating the kinase activation site, where the adenine moiety of ATP is packed like a sandwich between hydrophobic residues, while it is associated with the hinge region by hydrophilic contact. Typical kinase elements include the G-loop (glycine-rich residues forming the active site roof), A-loop, or activation loop crucial for kinase activation and deactivation, C-helix responsible for the selectivity of the active site, and the hinge region that plays a vital role in inhibitor binding. The ATP-binding site categorized into five distinct regions: adenine region where the adenine moiety of ATP forms a hydrogen bond with the hinge, hydrophobic region-I corresponds to the entrance pocket, hydrophobic region-II also known as the selectivity pocket is determined by an extremely conserved DFG (aspartate-phenylalanine-glycine) motif, a hydrophilic region where the ATP sugar binds, and a solvent-exposed region for phosphate binding. 


\subsubsection{Molecular Dynamic Simulation}

Although X-ray crystallography and molecular docking are powerful techniques for biological macromolecules, they are unable to examine the protein's flexibility and they provide a momentary binding mode. Therefore, MD simulation was used to investigate the ligand-protein interactions [36] and the conformational changes which occur in the structure of kinases with respect to motions. Based on the docking results, nine complexes were selected for further MD simulation to understand the binding mechanism of compound $\mathbf{1 0}$ and its stability against multiple kinases.

\section{c-Src}

The stereo view of the binding mode of Src (PDB ID: 2SRC) is depicted in Figure 8A. It was found that, initially, compound $\mathbf{1 0}$ was bound to the active site of Src kinase similar to a cognate ligand by making a hydrogen bond with the NH group of Met341 and CO group of Glu339, while these bonds were observed to undergo destabilization during the simulation. Comparatively, three new hydrogen bonds were formed, involving the side chain amino group of Lys295 (solvent accessible area) and the hydroxyl group of Ser345, which interact with the pyrazolopyrimidine scaffold located in the adenine region of Src kinase. The spatial position of the compound was found to be different from the observed dock pose because of major conformational changes during simulation.

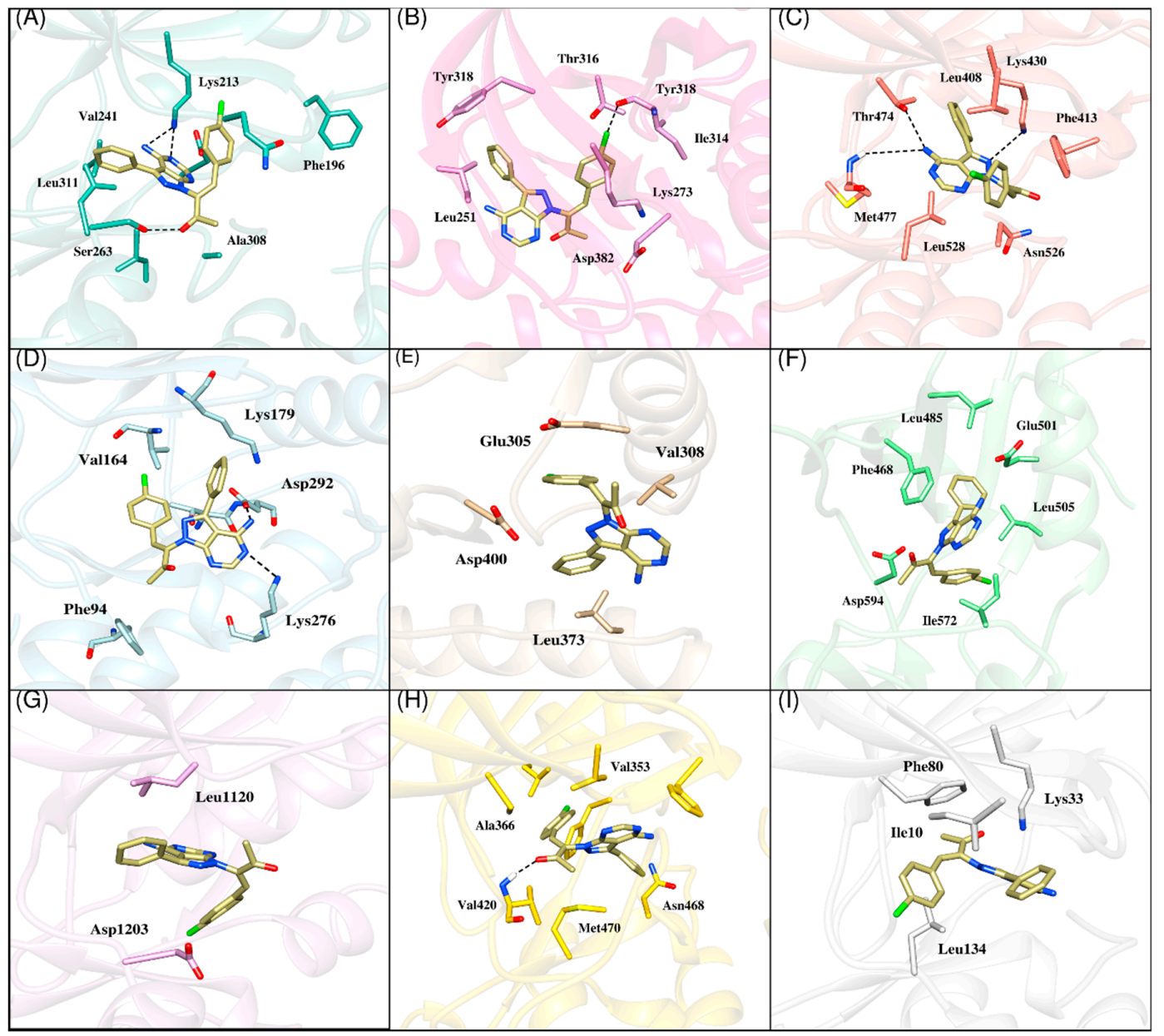

Figure 8. Binding mode of $\mathrm{Z}$ configuration of compound $\mathbf{1 0}$ (khaki) with the active site residues of (A) c-Src, (B) Lck, (C) Btk, (D) Akt, (E) Abl1, (F) Braf, (G) Alk, (H) PKC, and (I) Cdk2. Amino acid residues involved in crucial interactions are labeled. 
The activation loop in the DFG-in conformation provides enough space to accommodate the ring of compound 10, which may cause a collision with Phe405 of the DFG-out conformation. Moreover, distinct hydrophobic interactions were also observed with Leu273, and Val281 (hydrophobic region I) that maintain the binding mode of complexes. The MD results suggest that the non-flexible part of the compound might be the reason for its moderate activity as compared to the reference compound.

\section{Lck}

The binding elements responsible for the modest activity of Lck kinase are depicted in Figure 8B. Consistent with the results from other reported studies, compound $\mathbf{1 0}$ is well accommodated in the ATP site of Lck by forming multiple hydrophobic, $\pi$-stacking, $\pi$-cation, and Van der Waals interactions with Leu251, Ala271, Lys273, Thr316, Lys318, and Asp382. Due to the different conformation of the DFG motif, compound $\mathbf{1 0}$ slightly moves toward the adenine region with its core pyrimidine ring in the adenine region by forming a hydrophilic interaction with Met319. In the meantime, Phe385 of the DFG motif is involved in a weak hydrophobic interaction due to the far distance. The chloro-benzene ring engages the gatekeeper residue Thr316 via hydrophobic interaction, while the non-substituted benzene ring occupies the extended hydrophobic pocket, forming $\pi$-stacking and Van der Waals interactions with Leu251, Ala271, and Tyr318. The complex was further stabilized by the formation of a halogen bond between the backbone of the carbonyl oxygen of Ile314 and the fluorine of the compound 10 . In summary, a marked similarity of interaction was observed with the reference compound except for the hydrophilic interaction responsible for the inhibitory activity of Lck kinase.

\section{Btk}

The docked complex of BTK presented a number of hydrophilic and hydrophobic interactions with the active site residues Leu408, Val416, Lys430, Thr474, Glu475, Met477, Leu528, Asp539, and Phe540. The compound occupied the same position consistent with the reference compound. Molecular dynamics studies revealed that compound $\mathbf{1 0}$ binding to BTK, is stable and it was found to involve in hydrogen bond interactions with key residues of the glycine-rich P-loop like Leu408, Gly409, and Asp539. Transient hydrogen bond interactions were also detected with crucial active site residues Glu475 and Met477 of the hinge region, catalytic residue Lys430, and the DFG motif that is crucial for kinase activity, indicating that compound $\mathbf{1 0}$ probably has the appropriate interaction profile with BTK (Figure 8C).

\section{Akt}

According to the binding mode of the Akt complex [37], compound $\mathbf{1 0}$ adopts a Y-shape conformation, where the presence of residues Phe 469 and Phe 472 that are essential for the regulatory control of Akt1, make the pocket hydrophobic. Initially, the pyrimidine ring occupies the adenosine portion of the binding site, forming hydrogen bonding to the hinge region of the kinase through Ala230 (Figure 8D). During the simulation, this hydrogen bond is replaced by hydrophobic interactions, while the phenyl substituent presents a parallel aromatic interaction with Phe438. Moreover, residues Lys179, Leu181, and Val164 also stabilize the compound by making hydrophobic contact. In general, theoretical studies indicate that compound $\mathbf{1 0}$ stabilizes Akt via hydrophobic interactions; however, after losing its interactions with the hinge region, the gatekeeper residue and the DFG motif lead to its low kinase inhibitory properties.

\section{$\mathrm{Abl}$}

The binding mode of the Abl1 complex (Figure 8E) showed that the compound is accommodated in the lipophilic channel slightly away from the hinge region. The bent conformation of the molecule does not allow its tight binding to the ATP site. This resultant compound is unable to mimic interaction with the adenine moiety of ATP. Only a few hydrophobic interactions were observed with Glu305, Val308, Leu473, and Asp400, but these interactions were also not found to be persistent throughout the 
md simulation. It is hypothesized that the absence of specific interactions of compound $\mathbf{1 0}$ with the residues of the hinge region and DFG motif could be the reason for its inactivity.

\section{Braf}

According to the docking calculations, compound $\mathbf{1 0}$ is involved in a number of hydrophilic and hydrophobic interactions with Braf kinase. However, after a short $50 \mathrm{~ns}$ production run, the simulated binding mode provided a different picture to understand the selectivity trend. During the simulation, these non-bonded interactions were weakened due to loop flipping of the motif from the DGF-in to the DGF-out conformation. However, in order to accommodate the core pyrimidine ring, the benzene ring was required to tilt out of the plane due to restricted space. As a result of this movement, intermolecular interactions broke, which penalized the binding affinity of compound $\mathbf{1 0}$ for Braf (Figure 8F).

\section{Alk}

The binding interactions of the Alk with compound $\mathbf{1 0}$ are depicted in Figure 8G. The complex obtained after simulation indicates that the compound partially aligned on the reference compound ceritinib, and it was unable to form any hydrophilic interaction with the active site residues, especially with the hinge region. A similar type of binding mode was observed in the case of PKC (Figure $8 \mathrm{H}$ ) and Cdk2 (Figure 8I).

\subsubsection{Binding Free Energy Calculations}

MM/PBSA is considered as the best choice for predicting the binding affinities of a protein-ligand complex with implicit solvent at a low computational cost. It has the potential to recognize the true binding structure of the complex from docking. In the present study, MM/PBSA was used to re-rank the nine complexes after a short production run of $50 \mathrm{~ns}$. The calculated binding free energy of all complexes is presented in Table 4 [38]. The binding position and atomic interaction between protein kinases and ligand are the main factors that play a role in measuring the binding affinity. The predicted binding poses of compound $\mathbf{1 0}$ significantly overlaid with the reported inhibitors of c-Src, Lck, Btk, and Akt, but partially aligned in the case of Braf and Alk. According to Table 4, the binding free energy computed for c-Src, Lck, and Akt complexes was -20.63, -15.64, and -18.09, respectively, which were more stable than ALK, CDK2, and Abl1 kinases, agreeing with the selectivity profile observed experimentally. In order to comprehend the effect of the individual energy term in the binding process, total binding free energy was decomposed into the Eele, Evdw, EGB, and ESURF energy components. The values of these components indicated that van der Waals ( $\Delta \mathrm{Gvdw}$ ) energy contributed significantly to the total binding free energy. The superior contribution of Van der Waals interaction (Table 4) was in agreement with the fact that compound $\mathbf{1 0}$ mainly stabilizes via hydrophobic interactions with the kinases.

\section{Experimental Protocols}

\subsection{Materials and Methods}

Bromoacetone was purchased from ChemService Inc. (West Chester, PA, USA). Anhydrous dichloromethane, anhydrous pyridine, $N, N$-dimethylformamide (DMF), and other chemicals and reagents were purchased from Sigma-Aldrich Chemical Co. (Milwaukee, WI, USA). The chemical structures of final products were characterized by nuclear magnetic resonance spectra $\left({ }^{1} \mathrm{H} \mathrm{NMR}\right.$, ${ }^{13} \mathrm{C}$ NMR) determined on a Bruker (Billerica, MA, USA) NMR spectrometer (400 MHz) or a Varian (Silicon Valley, CA, USA) NMR spectrometer (500 MHz). ${ }^{13} \mathrm{C}$ NMR spectra were fully decoupled. Chemical shifts were reported in parts per millions (ppm) using deuterated solvent peak as the standard. The chemical structures of final products were confirmed by a high-resolution Biosystems QStar Elite (QStar Technologies, Denver, CO, USA) time-of-flight electrospray mass spectrometer. Details of procedures and spectroscopic data of the respective compounds are presented below. Final compounds 
were purified on a Phenomenex (Torrance, CA, USA) Prodigy $10 \mu \mathrm{m}$ ODS reverse-phase column $(2.1 \mathrm{~cm}$ $\times 25 \mathrm{~cm}$ ) with a Hitachi (Tokyo, Japan) HPLC system using a gradient system of acetonitrile or methanol and water $\left(\mathrm{CH}_{3} \mathrm{CN} / \mathrm{CH}_{3} \mathrm{OH} / \mathrm{H}_{2} \mathrm{O}, 0-100 \%\right.$, $\left.\mathrm{pH} 7.0,60 \mathrm{~min}\right)$. The purity of final products $(>99 \%)$ was confirmed by analytical HPLC. The analytical HPLC was performed on the Hitachi analytical HPLC system using a C18 Shimadzu (Kyoto, Japan) Premier $3 \mu \mathrm{m}$ column $(150 \mathrm{~cm} \times 4.6 \mathrm{~mm})$ using two different isocratic systems, and a flow rate of $1 \mathrm{~mL} / \mathrm{min}$ with UV detection at $265 \mathrm{~nm}$.

\subsection{Synthesis}

3-Phenyl-1H-pyrazolo[3,4- $d$ ] pyrimidin-4-amine (1): Compound $\mathbf{1}$ was synthesized according to a previously reported procedure [23].

1-(4-Amino-3-phenyl-1H-pyrazolo[3,4- $d$ ]pyrimidin-1-yl)propan-2-one (2): Compound 1 (156 mg, $0.73 \mathrm{mmol}$ ) and potassium carbonate $(200 \mathrm{mg}, 1.4 \mathrm{mmol})$ were taken in dry DMF $(10 \mathrm{~mL})$. Bromoacetone $(100 \mathrm{mg}, 0.72 \mathrm{mmol})$ was diluted with dry DMF $(5 \mathrm{~mL})$ and was added dropwise to the reaction mixture at room temperature. The reaction mixture was stirred for $4 \mathrm{~h}$ at room temperature. After completion of the reaction, the solvent was removed under reduced pressure, added water $(50 \mathrm{~mL})$ and extracted with dichloromethane. The organic layer was filtered through filter paper and dried over $\mathrm{Na}_{2} \mathrm{SO}_{4}$ (anhydrous). The crude product was further purified on silica gel flash chromatography using dichloromethane and methanol (0-20\%) as eluents. $160 \mathrm{mg}, 81 \%$ yield. ${ }^{1} \mathrm{H}-\mathrm{NMR}\left(\mathrm{CDCl}_{3}, 500 \mathrm{MHz}\right.$, $\delta$ ppm): $8.3(\mathrm{~s}, 1 \mathrm{H}), 7.7(\mathrm{~d}, J=11 \mathrm{~Hz}, 2 \mathrm{H}), 7.5-7.5(\mathrm{~m}, 3 \mathrm{H}), 5.2(\mathrm{~s}, 2 \mathrm{H}), 2.2(\mathrm{~s}, 3 \mathrm{H}) \cdot{ }^{13} \mathrm{C} \mathrm{NMR}\left(\mathrm{CDCl}_{3}\right.$, $125 \mathrm{MHz}, \delta$ ppm): 201.3, 158.1, 156.2, 155.2, 145.4, 132.8, 129.4, 129.3, 128.4, 98.4, 56.1, 27.1. HR-MS (ESI-TOF) $(m / z)$ : calculated for $\mathrm{C}_{14} \mathrm{H}_{13} \mathrm{~N}_{5} \mathrm{O}+\mathrm{H}^{+}$: 268.1193; found, $268.0852[\mathrm{M}+\mathrm{H}]^{+}$.

General Procedure for the Synthesis of Pyrazolopyrimidine Chalcones:

Compound 2 ( $26 \mathrm{mg}, 0.1 \mathrm{mmol})$ was dissolved in ethanol $(5 \mathrm{~mL})$. Sodium hydroxide $(5 \mathrm{mg}, 20 \mu \mathrm{L}$ of $250 \mathrm{mg} / \mathrm{mL} \mathrm{NaOH}$ solution in water) was added to the compound 2 solution. The reaction mixture solution was stirred for $15 \mathrm{~min}$. Then, a solution of $p$-methylbenzaldehyde $(24 \mathrm{mg}, 0.2 \mathrm{mmol})$ in ethanol $(15 \mathrm{~mL})$ was added to the reaction mixture. The reaction mixture was allowed to stir at room temperature for $5 \mathrm{~h}$. On completion of the reaction, the reaction mixture was neutralized with dilute acetic acid in ethanol and purified over reverse phase HPLC using water and methanol as eluents to obtain pure product 3 ( $22 \mathrm{mg}, 61 \%$ yield). A similar procedure was adopted for the synthesis of other pyrazolopyrimidine derivatives.

3-(4-Amino-3-phenyl-1H-pyrazolo[3,4- $d$ ]pyrimidin-1-yl)-4-p-tolylbut-3-en-2-one (3). (Yield: 61\%). ${ }^{1} \mathrm{H}-\mathrm{NMR}\left(\mathrm{CDCl}_{3}, 500 \mathrm{MHz}, \delta \mathrm{ppm}\right): 8.3(\mathrm{~s}, 1 \mathrm{H}), 7.7(\mathrm{~s}, 1 \mathrm{H}), 7.7(\mathrm{~d}, J=7 \mathrm{~Hz}, 2 \mathrm{H}), 7.6-7.5(\mathrm{~m}, 3 \mathrm{H}), 7.0(\mathrm{~d}$, $J=8.2 \mathrm{~Hz}, 2 \mathrm{H}), 6.9(\mathrm{~d}, J=8.2 \mathrm{~Hz}, 2 \mathrm{H}), 2.3(\mathrm{~s}, 3 \mathrm{H}), 2.9(\mathrm{~s}, 3 \mathrm{H}) .{ }^{13} \mathrm{C} \mathrm{NMR}\left(\mathrm{CDCl}_{3}, 125 \mathrm{MHz}, \delta \mathrm{ppm}\right): 194.3$, $157.9,156.9,155.8,146.8,141.8,140.5,132.7,131.8,130.7,129.6,129.5,129.4,128.5,26.1,21.5$. HR-MS (ESI-TOF) $(m / z)$ : calculated for $\mathrm{C}_{22} \mathrm{H}_{19} \mathrm{~N}_{5} \mathrm{O}+\mathrm{H}^{+}$: 370.1662; found, $370.1534[\mathrm{M}+\mathrm{H}]^{+}$.

3-(4-Amino-3-phenyl-1H-pyrazolo[3,4-d]pyrimidin-1-yl)-4-m-tolylbut-3-en-2-one (4). (Yield: 64\%). ${ }^{1} \mathrm{H}-\mathrm{NMR}\left(\mathrm{CDCl}_{3}, 500 \mathrm{MHz}, \delta \mathrm{ppm}\right): 8.3(\mathrm{~s}, 1 \mathrm{H}), 7.9(\mathrm{~s}, 1 \mathrm{H}), 7.7(\mathrm{~d}, J=7 \mathrm{~Hz}, 2 \mathrm{H}), 7.6-7.5(\mathrm{~m}, 3 \mathrm{H})$, 7.1-7.0 (m, 2H), $6.8(\mathrm{~s}, 1 \mathrm{H}), 6.7(\mathrm{~d}, J=10 \mathrm{~Hz}, 1 \mathrm{H}), 2.3(\mathrm{~s}, 3 \mathrm{H}), 2.2(\mathrm{~s}, 3 \mathrm{H}) .{ }^{13} \mathrm{C} \mathrm{NMR}\left(\mathrm{CDCl}_{3}, 125 \mathrm{MHz}\right.$, $\delta$ ppm): 194.3, 157.8, 155.1, 154.9, 146.8, 140.6, 133.9, 131.7, 131.5, 130.2, 129.5, 129.4,128.6, 128.4, 26.2, 21.3. HR-MS (ESI-TOF) $(\mathrm{m} / \mathrm{z})$ : calculated for $\mathrm{C}_{22} \mathrm{H}_{19} \mathrm{~N}_{5} \mathrm{O}+\mathrm{H}^{+}$: 370.1662; found, $370.1454[\mathrm{M}+\mathrm{H}]^{+}$.

3-(4-Amino-3-phenyl-1H-pyrazolo[3,4-d]pyrimidin-1-yl)-4-p-biphenylbut-3-en-2-one (5). (Yield: 59\%). ${ }^{1} \mathrm{H}-\mathrm{NMR}\left(\mathrm{CDCl}_{3}, 500 \mathrm{MHz}, \delta \mathrm{ppm}\right): 8.0(\mathrm{~s}, 1 \mathrm{H}), 7.9(\mathrm{~s}, 1 \mathrm{H}), 7.7(\mathrm{~d}, J=8.2 \mathrm{~Hz}, 2 \mathrm{H}), 7.6-7.6(\mathrm{~m}, 3 \mathrm{H})$, 7.6-7.4 (m, 9H), 2.3 (s, 3H). ${ }^{13} \mathrm{C}$ NMR (CDCl $\left.3,125 \mathrm{MHz}, \delta \mathrm{ppm}\right): 191.9,147.2,135.2,131.1,130.3,129.9$, $129.9,129.8,129.4,129.0,128.7,128.5,128.5,127.7,127.3,127.3,127.2,127.1,127.0,126.1,22.5$. HR-MS (ESI-TOF) $(m / z)$ : calculated for $\mathrm{C}_{27} \mathrm{H}_{21} \mathrm{~N}_{5} \mathrm{O}+\mathrm{H}^{+}$: 432.1819; found, $432.1616[\mathrm{M}+\mathrm{H}]^{+}$.

3-(4-Amino-3-phenyl-1H-pyrazolo[3,4-d]pyrimidin-1-yl)-4-(4-methoxyphenyl)but-3-en-2-one (6). (Yield: 63\%). ${ }^{1} \mathrm{H}-\mathrm{NMR}\left(\mathrm{CDCl}_{3}, 500 \mathrm{MHz}, \delta \mathrm{ppm}\right): 8.3(\mathrm{~s}, 1 \mathrm{H}), 7.9(\mathrm{~s}, 1 \mathrm{H}), 7.7(\mathrm{~d}, J=7 \mathrm{~Hz}, 2 \mathrm{H}), 7.6-7.5(\mathrm{~m}, 3 \mathrm{H})$, 
$6.9(\mathrm{~d}, J=8.9 \mathrm{~Hz}, 2 \mathrm{H}), 6.7(\mathrm{~d}, J=8.9 \mathrm{~Hz}, 2 \mathrm{H}), 3.7(\mathrm{~s}, 3 \mathrm{H}), 2.3(\mathrm{~s}, 3 \mathrm{H}) .{ }^{13} \mathrm{C} \mathrm{NMR}\left(\mathrm{CDCl}_{3}, 125 \mathrm{MHz}, \delta \mathrm{ppm}\right)$ : 194.2, 161.9, 158.0, 156.9, 155.7, 146.9, 140.2, 132.8, 132.7, 130.6, 129.5, 129.4, 128.5, 124.3, 114.4, 98.9, 55.3, 26.0. HR-MS (ESI-TOF) $(\mathrm{m} / \mathrm{z})$ : calculated for $\mathrm{C}_{22} \mathrm{H}_{19} \mathrm{~N}_{5} \mathrm{O}_{2}+\mathrm{H}^{+}$: 386.1612; found, $386.1573[\mathrm{M}+\mathrm{H}]^{+}$.

3-(4-Amino-3-phenyl-1H-pyrazolo[3,4-d]pyrimidin-1-yl)-4-(4-(dimethylamino)phenyl)but-3-en-2-one (7). (Yield: $66 \%) .{ }^{1} \mathrm{H}-\mathrm{NMR}\left(\mathrm{CDCl}_{3}, 500 \mathrm{MHz}, \delta \mathrm{ppm}\right): 8.3(\mathrm{~s}, 1 \mathrm{H}), 7.9(\mathrm{~s}, 1 \mathrm{H}), 7.7(\mathrm{~d}, J=8 \mathrm{~Hz}, 2 \mathrm{H})$, 7.6-7.5 (m, 3H), $6.8(\mathrm{~d}, J=9.1 \mathrm{~Hz}, 2 \mathrm{H}), 6.4(\mathrm{~d}, J=9.1 \mathrm{~Hz}, 2 \mathrm{H}), 2.9(\mathrm{~s}, 6 \mathrm{H}), 2.3(\mathrm{~s}, 3 \mathrm{H}) .{ }^{13} \mathrm{C} \mathrm{NMR}\left(\mathrm{CDCl}_{3}\right.$, $125 \mathrm{MHz}, \delta$ ppm): 194.4, 162.1, 158.2, 157.1, 155.9, 147.1, 140.4, 133.0, 132.9, 130.8, 129.7, 129.6, 128.7, 124.5, 114.6, 99.0, 41.4, 26.3. HR-MS (ESI-TOF) $(m / z)$ : calculated for $\mathrm{C}_{23} \mathrm{H}_{22} \mathrm{~N}_{6} \mathrm{O}+\mathrm{H}^{+}$: 399.1928; found, $399.1981[\mathrm{M}+\mathrm{H}]^{+}$.

3-(4-Amino-3-phenyl-1H-pyrazolo[3,4-d]pyrimidin-1-yl)-pent-3-en-2-one (8). (Yield: 60\%). ${ }^{1} \mathrm{H}$-NMR $\left(\mathrm{CDCl}_{3}, 500 \mathrm{MHz}, \delta \mathrm{ppm}\right): 8.37(\mathrm{~s}, 1 \mathrm{H}), 7.8-7.7(\mathrm{~m}, 2 \mathrm{H}), 7.6-7.5(\mathrm{~m}, 3 \mathrm{H}), 7.4(\mathrm{q}, J=7.1 \mathrm{~Hz}, 1 \mathrm{H}), 2.3(\mathrm{~s}$, $3 \mathrm{H}), 1.8(\mathrm{~d}, J=7 \mathrm{~Hz}, 3 \mathrm{H}) .{ }^{13} \mathrm{C} \mathrm{NMR}\left(\mathrm{CDCl}_{3}, 100 \mathrm{MHz}, \delta \mathrm{ppm}\right): 157.9,156.3,154.8,141.7,132.6,129.6$, 129.5, 129.5, 128.5. 128.4, 98.3, 56.2, 26.1, 14.6. HR-MS (ESI-TOF) $(m / z)$ : calcd for $\mathrm{C}_{16} \mathrm{H}_{15} \mathrm{~N}_{5} \mathrm{O}+\mathrm{H}^{+}$: 294.1349; found, $294.099[\mathrm{M}+\mathrm{H}]^{+}$.

3-(4-Amino-3-phenyl-1H-pyrazolo[3,4-d]pyrimidin-1-yl)-4-(3-nitrophenyl)but-3-en-2-one (9). (Yield: $44 \%) .{ }^{1} \mathrm{H}-\mathrm{NMR}\left(\mathrm{CDCl}_{3}, 500 \mathrm{MHz}, \delta \mathrm{ppm}\right): 8.3(\mathrm{~s}, 1 \mathrm{H}), 7.9(\mathrm{~s}, 1 \mathrm{H}), 7.7(\mathrm{~d}, J=7 \mathrm{~Hz}, 2 \mathrm{H}), 7.5-7.5(\mathrm{~m}$, $3 \mathrm{H}), 6.9(\mathrm{~d}, J=8.9 \mathrm{~Hz}, 2 \mathrm{H}), 6.7(\mathrm{~d}, J=8.9 \mathrm{~Hz}, 1 \mathrm{H}), 2.3(\mathrm{~s}, 3 \mathrm{H}) .{ }^{13} \mathrm{C} \mathrm{NMR}\left(\mathrm{CDCl}_{3}, 125 \mathrm{MHz}, \delta \mathrm{ppm}\right)$ : 194.2, 161.9, 158.0, 156.9, 155.7, 146.9, 140.2, 132.8, 132.7, 130.6, 129.5, 129.4, 128.5, 124.3, 114.4, 98.9, 55.3, 26.0. HR-MS (ESI-TOF) $(\mathrm{m} / \mathrm{z})$ : calculated for $\mathrm{C}_{21} \mathrm{H}_{16} \mathrm{~N}_{6} \mathrm{O}_{3}+\mathrm{H}^{+}$: 401.1357; found, $401.0957[\mathrm{M}+\mathrm{H}]^{+}$, $801.1652[2 \mathrm{M}+\mathrm{H}]^{+}$.

3-(4-Amino-3-phenyl-1H-pyrazolo[3,4-d]pyrimidin-1-yl)-4-(4-chlorophenyl)but-3-en-2-one (10). (Yield: 57\%). ${ }^{1} \mathrm{H}-\mathrm{NMR}\left(\mathrm{CDCl}_{3}, 500 \mathrm{MHz}, \delta \mathrm{ppm}\right): 8.1(\mathrm{~s}, 1 \mathrm{H}), 7.9(\mathrm{~s}, 1 \mathrm{H}), 7.6(\mathrm{~m}, 2 \mathrm{H}), 7.5-7.5(\mathrm{~m}, 3 \mathrm{H}), 7.2$ $(\mathrm{d}, J=8.6 \mathrm{~Hz}, 2 \mathrm{H}), 6.9(\mathrm{~d}, J=8.6 \mathrm{~Hz}, 2 \mathrm{H}), 2.4(\mathrm{~s}, 3 \mathrm{H}) .{ }^{13} \mathrm{C} \mathrm{NMR}\left(\mathrm{CDCl}_{3}, 125 \mathrm{MHz}, \delta \mathrm{ppm}\right): 192.4$, 153.7, 153.5, 149.5, 147.2, 140.6, 137.9, 132.5, 131.5, 131.3, 130.9, 130.4, 130.1, 129.5, 128.1, 97.6, 55.3, 25.8 . HR-MS (ESI-TOF) $\left(\mathrm{m} / \mathrm{z}\right.$ ): calculated for $\mathrm{C}_{21} \mathrm{H}_{16} \mathrm{ClN}_{5} \mathrm{O}+\mathrm{H}^{+}$: 390.1116; found, $390.0951[\mathrm{M}+1]^{+}$.

3-(4-Amino-3-phenyl-1H-pyrazolo[3,4-d]pyrimidin-1-yl)-4-(2,4-dichlorophenyl)but-3-en-2-one (11). (Yield: 58\%). ${ }^{1} \mathrm{H}-\mathrm{NMR}\left(\mathrm{CDCl}_{3}, 500 \mathrm{MHz}, \delta \mathrm{ppm}\right): 8.3(\mathrm{~s}, 1 \mathrm{H}), 7.9(\mathrm{~s}, 1 \mathrm{H}), 7.7(\mathrm{~d}, J=7 \mathrm{~Hz}, 2 \mathrm{H}), 7.5-7.5$ $(\mathrm{m}, 3 \mathrm{H}), 6.9(\mathrm{~s}, 1 \mathrm{H}), 6.7(\mathrm{~d}, J=8.6 \mathrm{~Hz}, 2 \mathrm{H}), 2.6(\mathrm{~s}, 3 \mathrm{H}) .{ }^{13} \mathrm{C} \mathrm{NMR}\left(\mathrm{CDCl}_{3}, 125 \mathrm{MHz}, \delta \mathrm{ppm}\right): 192.2,153.7$, $136.9,136.2,130.9,130.2,130.1,129.8,129.0,128.2,128.1,127.5,127.5,97.6,66.4,53.4,25.9$. HR-MS (ESI-TOF) (m/z): calculated for $\mathrm{C}_{21} \mathrm{H}_{15} \mathrm{Cl}_{2} \mathrm{~N}_{5} \mathrm{O}+\mathrm{H}^{+}$: 424.0726; found, $424.1220[\mathrm{M}+\mathrm{H}]^{+}$.

3-(4-Amino-3-phenyl-1H-pyrazolo[3,4-d]pyrimidin-1-yl)-4-(2-chlorophenyl)but-3-en-2-one (12). (Yield: 57\%). ${ }^{1} \mathrm{H}-\mathrm{NMR}\left(\mathrm{CDCl}_{3}, 500 \mathrm{MHz}, \delta \mathrm{ppm}\right): 8.3(\mathrm{~s}, 1 \mathrm{H}), 8.2(\mathrm{~s}, 1 \mathrm{H}), 7.6-7.5(\mathrm{~m}, 5 \mathrm{H}), 7.3-7.2(\mathrm{~m}, 4 \mathrm{H}), 2.6$ (s, 3H). ${ }^{13} \mathrm{C}-\mathrm{NMR}\left(\mathrm{CDCl}_{3}, 125 \mathrm{MHz}, \delta \mathrm{ppm}\right): 153.6,153.3,149.1,146.5,138.2,132.0,130.8,130.2,130.1$, 129.3, 128.9, 128.1, 126.9, 52.5, 25.9. HR-MS (ESI-TOF) $(\mathrm{m} / \mathrm{z})$ : calcd for $\mathrm{C}_{21} \mathrm{H}_{16} \mathrm{ClN}_{5} \mathrm{O}+\mathrm{H}^{+}$: 390.1116 ; found, $390.1427[\mathrm{M}+\mathrm{H}]^{+}$.

3-(4-Amino-3-phenyl-1H-pyrazolo[3,4-d]pyrimidin-1-yl)-4-(2-fluorophenyl)but-3-en-2-one (13). (Yield: 62\%). ${ }^{1} \mathrm{H}-\mathrm{NMR}\left(\mathrm{CDCl}_{3}, 500 \mathrm{MHz}, \delta \mathrm{ppm}\right): 8.3(\mathrm{~s}, 1 \mathrm{H}), 7.9(\mathrm{~s}, 1 \mathrm{H}), 7.7(\mathrm{~d}, J=7 \mathrm{~Hz}, 2 \mathrm{H}), 7.6-7.5(\mathrm{~m}$, $3 \mathrm{H}), 7.2-6.9(\mathrm{~m}, 4 \mathrm{H}), 2.3(\mathrm{~s}, 3 \mathrm{H}) .{ }^{13} \mathrm{C} \mathrm{NMR}\left(\mathrm{CDCl}_{3}, 125 \mathrm{MHz}, \delta \mathrm{ppm}\right): 193.8,158.1,155.6,147.4,132.8$, 132.7, 130.3, 131.7, 129.7, 129.5, 129.5, 129.3, 129.2, 128.4, 128.4, 128.4, 98.7, 26.2. HR-MS (ESI-TOF) $(\mathrm{m} / \mathrm{z})$ : calculated for $\mathrm{C}_{21} \mathrm{H}_{16} \mathrm{FN}_{5} \mathrm{O}+\mathrm{H}^{+}$: 374.1412; found, $374.1526[\mathrm{M}+\mathrm{H}]^{+}$.

3-(4-Amino-3-phenyl-1H-pyrazolo[3,4-d]pyrimidin-1-yl)-4-(4-fluorophenyl)but-3-en-2-one (14). (Yield: 64\%). ${ }^{1} \mathrm{H}-\mathrm{NMR}\left(\mathrm{CDCl}_{3}, 500 \mathrm{MHz}, \delta \mathrm{ppm}\right): 8.1(\mathrm{~s}, 1 \mathrm{H}), 7.8(\mathrm{~s}, 1 \mathrm{H}), 7.5-7.4(\mathrm{~m}, 5 \mathrm{H}), 6.9(\mathrm{dd}, J=14 \mathrm{~Hz}$, $J=5.6 \mathrm{~Hz}, 2 \mathrm{H}), 6.8(\mathrm{t}, J=7.6 \mathrm{~Hz}, 2 \mathrm{H}), 2.4(\mathrm{~s}, 3 \mathrm{H}) .{ }^{13} \mathrm{C} \mathrm{NMR}\left(\mathrm{CDCl}_{3}, 125 \mathrm{MHz}, \delta \mathrm{ppm}\right): 192.5,153.7$, 153.5, 147.2, 140.7, 132.5, 132.4, 130.9, 130.1, 130.0, 128.1, 128.1, 116.7, 116.5, 25.7. HR-MS (ESI-TOF) $(\mathrm{m} / \mathrm{z})$ : calculated for $\mathrm{C}_{21} \mathrm{H}_{16} \mathrm{FN}_{5} \mathrm{O}+\mathrm{H}^{+}$: 374.1412; found, $374.1679[\mathrm{M}+\mathrm{H}]^{+}$. 
3-(4-Amino-3-phenyl-1H-pyrazolo[3,4-d]pyrimidin-1-yl)-4-phenyl but-3-en-2-one (15). (Yield: 59\%). ${ }^{1} \mathrm{H}-\mathrm{NMR}\left(\mathrm{CDCl}_{3}, 500 \mathrm{MHz}, \delta \mathrm{ppm}\right): 8.2(\mathrm{~s}, 1 \mathrm{H}), 8.0(\mathrm{~s}, 1 \mathrm{H}), 7.7-7.6(\mathrm{~m}, 5 \mathrm{H}), 7.4-6.9(\mathrm{~m}, 5 \mathrm{H}), 2.5(\mathrm{~s}, 3 \mathrm{H})$.

${ }^{13} \mathrm{C}-\mathrm{NMR}\left(\mathrm{CDCl}_{3}, 125 \mathrm{MHz}, \delta \mathrm{ppm}\right): 192.5,153.7,153.5,147.2,140.7,132.5,132.4,130.9,130.1,130.0$, 128.1, 128.1, 116.7, 116.5, 25.7. HR-MS (ESI-TOF) $(\mathrm{m} / \mathrm{z})$ : calculated for $\mathrm{C}_{21} \mathrm{H}_{17} \mathrm{~N}_{5} \mathrm{O}+\mathrm{H}^{+}$: 356.1506; found, $356.1703[\mathrm{M}+\mathrm{H}]^{+}$.

\subsection{Kinase Enzyme Assay}

\subsection{1. c-Src Kinase Activity Assay}

The effect of compounds on the activity of $c$-Src kinase was assessed using a Transcreener ${ }^{\circledR}$ ADP [2,8] fluorescence intensity (FI) Assay, from Bell Brook Labs, Madison, WI, USA, (catalog no. 3013-1K) according to the manufacturer's protocol. A 384-well low-volume black non-binding surface round-bottom microplate was purchased from Corning Inc. (Corning, NY, USA) (\#3676). In summary, the kinase reaction was started in the 384-well low volume black microplate with the incubation of $2.5 \mu \mathrm{L}$ of the reaction cocktail $\left(0.7 \mathrm{nM}\right.$ of $\mathrm{His}_{6}-\mathrm{Src}$ kinase domain in kinase buffer) with $2.5 \mu \mathrm{L}$ of prediluted compounds (dissolved in 10\% DMSO, $4 \times$ target concentration) for $10 \mathrm{~min}$ at room temperature using microplate shaker. The reaction cocktail was made using the kinase buffer HEPES (200 mM, pH 7.5), $\mathrm{MgCl}_{2}$ (16 mM), EGTA (8 mM), DMSO (4\%), Brij-35 (0.04\%), and 2-mercaptoethanol (43 mM). The kinase reaction was started by adding $5 \mu \mathrm{L}$ of ATP/substrate $(40 \mu \mathrm{M} / 600 \mu \mathrm{M})$ cocktail and incubated for $30 \mathrm{~min}$ at room temperature on a microplate shaker. Src optimal peptide (AEEEIYGEFEAKKKK) was used as the substrate for the kinase reaction. The kinase reaction was stopped by adding $10 \mu \mathrm{L}$ of the $1 \times$ ADP Detection Mixture to the enzyme reaction mixture and mixed using a plate shaker. The mixture was incubated at room temperature for $1 \mathrm{~h}$, and the fluorescence intensity was measured. The $1 \times$ ADP Detection Mixture was prepared by adding ADP ${ }^{2}$ Antibody-IRDyeR QC-1 (10 $\left.\mu \mathrm{g} / \mathrm{mL}\right)$ and ADP Alexa594 Tracer $(8 \mathrm{nM})$ to Stop and Detect Buffer $\mathrm{B}(1 \times)$. The fluorescence Intensity measurements were performed using a fluorescence intensity optical module using the excitation of $580 \mathrm{~nm}$ and emission of $630 \mathrm{~nm}$ with bandwidths of $10 \mathrm{~nm}$ by Optima, BMG Labtech microplate reader (BMG Labtech, Ortenberg, Germany). The IC $_{50}$ values of the compounds were calculated using ORIGIN 6.0 (Origin Lab, Microcal Software, Inc. Northhampton, MA, USA) software. $\mathrm{IC}_{50}$ is the concentration of the compound that inhibited enzyme activity by $50 \%$. All the experiments were carried out in triplicate.

3.3.2. Evaluation of Compound 10 Against a Panel of Kinases (Abl1, Akt1, Alk, Braf, Btk, Cdk2, cSrc, Lck, and PKCa)

Compound 10 was evaluated for inhibitory activity against Abl1, Akt1, Alk, Braf, Btk, Cdk2, cSrc, Lck, and PKCa, in duplicate by Reaction Biology Corporation. Compounds were tested in a five-dose $\mathrm{IC}_{50}$ mode with four-fold serial dilution starting at $20 \mu \mathrm{M}$. Control compounds Staurosporine and GW5074 were tested in a 10-dose $\mathrm{IC}_{50}$ starting at $20 \mu \mathrm{M}$ with a four-fold or three-fold serial dilution, respectively. All kinase reactions were performed at $200 \mu \mathrm{M}$ ATP. The compounds were pre-incubated with the enzyme and substrate mixture about $20 \mathrm{~min}$, and then ATP was added to start the reaction. The reaction was $2 \mathrm{~h}$ at room temperature. Curve fits were performed when the activities at the highest concentration of compounds were less than $65 \%$. The detailed experimental procedure is provided here. An $\mathrm{IC}_{50}$ value of less than $0.04 \mathrm{nM}$ or higher than $1 \mu \mathrm{M}$ is estimated based on the best curve fitting available. The substrates for kinases are shown in Table 5. 
Table 5. Substrates used for kinases.

\begin{tabular}{ccccc}
\hline Kinases & $\begin{array}{c}\text { Kinase } \\
\text { (Invitrogen) Cat\# }\end{array}$ & $\begin{array}{c}\text { Kinase Conc. in } \\
\text { Reaction (nM) }\end{array}$ & Substrate & $\begin{array}{c}\text { Substrate Conc. } \\
\text { in Reaction }\end{array}$ \\
\hline Abl1 & PR4348B & 0.25 & ABLtide & $20 \mu \mathrm{M}$ \\
c-Src & P3044 & 0.6 & $\mathrm{pEY}$ & $0.2 \mathrm{mg} / \mathrm{mL}$ \\
Akt1 & PR3878D & 8 & Crosstide & $20 \mu \mathrm{M}$ \\
Alk & PV3867 & 1.5 & $\mathrm{pEY}$ & $0.2 \mathrm{mg} / \mathrm{mL}$ \\
Cdk2/Cyclin A1 & C29-10BG & 15 & Histone H1 & $20 \mu \mathrm{M}$ \\
PKCa & PR1455C & 0.5 & Histone H1 + Lipid & $20 \mu \mathrm{M}$ \\
Braf & PR6995A & 30 & Activator & $5 \mu \mathrm{M}$ \\
Lck & P3043 & 8 & $\mathrm{pEY}+$ Manganese & $0.2 \mathrm{mg} / \mathrm{mL}$ \\
Btk & PV3363 & 8 & $\mathrm{pEY}$ & $0.2 \mathrm{mg} / \mathrm{mL}$ \\
\hline
\end{tabular}

Base Reaction buffer was prepared from $20 \mathrm{mM}$ Hepes (pH 7.5), $10 \mathrm{mM} \mathrm{MgCl}_{2}, 1 \mathrm{mM} \mathrm{EGTA}, 0.02 \%$ Brij35, $0.02 \mathrm{mg} / \mathrm{mL}$ BSA, $0.1 \mathrm{mM} \mathrm{Na} \mathrm{VO}_{4}, 2 \mathrm{mM}$ DTT, and 1\% DMSO. Required cofactors were added individually to each kinase reaction. Testing compounds were dissolved in 100\% DMSO to a specific concentration. The serial dilution was conducted by Integra Viaflo Assist in DMSO. The substrate was prepared in a freshly prepared reaction buffer. The required cofactors for each kinase were added to the substrate solution. The kinase was added into the substrate solution, and the solution was gently mixed. The compounds in $100 \%$ DMSO were added into the kinase reaction mixture by Acoustic technology (Echo550; nanoliter range) and incubated for $20 \mathrm{~min}$ at room temperature. P-ATP (Specific activity $10 \mu \mathrm{Ci} / \mu \mathrm{l}$ ) was added into the reaction mixture to initiate the reaction. The mixture was incubated for $2 \mathrm{~h}$ at room temperature. The radioactivity was detected using the filter-binding method. The kinase activity data were expressed as the percentage remaining kinase activity in test samples compared to vehicle (dimethyl sulfoxide) reactions. $\mathrm{IC}_{50}$ values, and curve fits were obtained using GraphPad Prism software (version 7, Informer Technologies, Inc., Los Angeles, CA, USA).

\subsection{Cell Culture and Cell Proliferation Assay}

\subsubsection{Cell Culture}

Human leukemia cell line CCRF-CEM (ATCC no. CCL-119), human ovarian adenocarcinoma cell line SK-OV-3 (ATCC no. HTB-77), human breast carcinoma cell line MDA-MB-231 (ATCC no.HTB-26), and human colon adenocarcinoma cell line HT-29 (ATCC no. HTB-38) were obtained from American Type Culture Collection. Cells were grown on $75 \mathrm{~cm}^{2}$ cell culture flasks with RPMI-16 medium (for leukemia cells) and EMEM (Eagle's minimum essential medium) (for SK-OV-3, HT-29, MDA-MB-231 cells), supplemented with $10 \%$ fetal bovine serum (FBS), and $1 \%$ penicillin-streptomycin solution $(10,000$ units of penicillin and $10 \mathrm{mg}$ of streptomycin in $0.9 \% \mathrm{NaCl})$ in a humidified atmosphere of $5 \%$ $\mathrm{CO}_{2}, 95 \%$ air at $37^{\circ} \mathrm{C}$.

\subsubsection{Cell Proliferation Assay}

The cell proliferation assay was carried out using a CellTiter 96 aqueous one-solution cell proliferation assay kit (Promega, Madison, WI, USA). Briefly, upon reaching about $75-80 \%$ confluence, 5000 cells/well were plated in 96-well microplate in $100 \mu \mathrm{L}$ of the medium. After seeding for $24 \mathrm{~h}$, the cells were treated with $50 \mu \mathrm{M}$ compound in triplicate. Doxorubicin $(10 \mu \mathrm{M})$ was used as a positive control. At the end of the sample exposure period $(72 \mathrm{~h}), 20 \mu \mathrm{L}$ of CellTiter 96 aqueous solution was added. The plate was returned to the incubator for $1 \mathrm{~h}$ in a humidified atmosphere at $37^{\circ} \mathrm{C}$. The absorbance of the formazan product was measured at $490 \mathrm{~nm}$ using a microplate reader. The blank control was recorded by measuring the absorbance at $490 \mathrm{~nm}$ with wells containing medium mixed with CellTiter 96 aqueous solution but no cells. The percentage of cell survival was calculated as the OD value of cells treated with test compound - OD value of culture medium/(OD value of control cells 
- OD value of culture medium) $\times 100 \%$. The same strategy was used for generating a dose-response graph for compound $\mathbf{1 0 .}$

\subsection{Molecular Modeling}

\subsubsection{Target Fishing}

Potential targets were identified against the phenylpyrazolopyrimidine scaffold using a combination of information integration, chemometric methods, and data mining approaches. Initially, targets involved in breast, ovarian, and colorectal cancer pathways were extracted from the database of KEGG. In the next step, protein network association servers STRING, STITCH, and SEA were used to characterize the protein-ligand interactions. Similarly, the PhPP scaffold was also searched using different search engines to understand protein-ligand interactions. Based on the above-mentioned information, we selected fourteen different targets, including Btk, Itk, c-Src, EGFR [39], Braf, Fyn, Lyn, Hck, Cdk2/4, Alk, Akt1 Lck, PKC, and Abl1 kinase. To understand the binding mechanism of active compound 10 against all selected targets, molecular docking and MD simulations were performed.

\subsubsection{Preparation of Complexes}

Crystal structures of the Anaplastic lymphoma kinase [PDB ID: 4MKC], ABL1 kinase [PDB ID: 6HD4], Protein kinase B also known as AKT [PDB ID: 4GV1], bruton tyrosine kinase [PDB ID: 6DIS], BRAF [PDB ID: 6B8U], c-Src kinase [PDB ID: 2SRC], CDK2 [PDB ID: 4KD1], LCK [PDB ID: 2OFU], ITK [PDB ID: 4HUC], EGFR [PDB ID: 4HJO], FYN [PDB ID: 2DQ7], LYN [PDB ID: 2ZV9], HCK [PDB ID: 1QCF], and PKCa [PDB ID: 3IW4] were retrieved from RCSB Protein Databank. The missing part of the starting structures was constructed using MOE software (Molecular Operating Environment, v2016.08, 2016). Compound partial charges were derived with the MMFF94x force field. All stabilizing agents, water molecules, and ions present in the crystal structures were removed. The protonate 3D module in MOE was used for assigning the protonation state to every titratable residue at physiological conditions within the complexes. MOE docking suite was employed for docking studies. The standard default settings were used with the London $\mathrm{dG}$ scoring function as a fitness function in all calculations.

\subsubsection{Simulations}

After analysis of docking results, nine complexes were subjected to all-atom MD simulation using the graphics processing unit (GPU) version of the PMEMD.cuda engine provided with Amber18 [40]. The gaff [41] and ff14SB force field [42] were implemented to ligand and protein in all simulations, respectively. Each complex was neutralized by adding counter ions, and the systems were solvated by a cubic box of the TIP3P water model with a $10 \AA$ box size from the solute. Systems were relaxed by adjusting hydrogen position, while 1000 cycles of steepest descent, and 5000 cycles of the conjugate gradient with restraints of $100 \mathrm{kcal} \cdot \mathrm{mol}^{-1}$ were applied on heavy atoms. Finally, another minimization of 5000 steps was performed to relax the system without any restraint. It was followed by equilibration of each system by gradual heating from $0 \mathrm{~K}$ to $300 \mathrm{~K}$ in the NVT ensemble. Systems were further equilibrated under the NPT ensemble (Pressure $=1 \mathrm{~atm}$ ). The production run of $50 \mathrm{~ns}$ was performed for each system using the isothermal-isobaric (NPT) ensemble at constant temperature and pressure with periodic boundary conditions. The Particle Mesh Ewald Method (PMEM) [43] was used to calculate long-range electrostatic interactions with cut off value of $8 \AA$ for the non-bonded (electrostatics and Van der Waals) interactions. An integration time step of $2 \mathrm{fs}$ was set to integrate Newton's equations of motion. The SHAKE algorithm [44] was employed to restrain the bonds involving hydrogen atoms. The trajectories were analyzed using CPPTRAJ module incorporated in AMBER suite. All visualization was performed using Chimera and VMD. 


\subsubsection{MM/PBSA Calculations}

The binding free energy calculation for each complex was performed using the MM(GB/PB)SA method based on 1000 frames extracted from the 50 ns trajectory. The equations associated with binding free energy calculation were as follows:

$$
\begin{gathered}
\Delta \mathrm{G}=\mathrm{G}_{\text {complex }}-\left(\mathrm{G}_{\text {receptor }}+\mathrm{G}_{\text {compound }}\right) \\
\mathrm{G}=\mathrm{H}-\mathrm{TS} \\
\mathrm{H}=\mathrm{E}_{\mathrm{vdw}}+\mathrm{E}_{\text {ele }}+\mathrm{E}_{\text {int }}+\mathrm{G}_{\mathrm{gb}}+\mathrm{G}_{\text {surf }}
\end{gathered}
$$

The total binding free energy is $\Delta G$, whereas the free energies for the complex, receptor, and compound are represented as $G_{\text {complex }}, G_{\text {receptor, }}$ and $G_{\text {compound, }}$ respectively. The terms $H$ and $\mathrm{T} \Delta \mathrm{S}$ were used for the contribution of enthalpy and entropy. The binding free energy further decomposed into electrostatic $\left(E_{\text {ele }}\right)$, Van der Waals interaction $\left(E_{v d w}\right)$, internal energy $\left(E_{\text {int }}\right)$, and polar $\left(\mathrm{G}_{\mathrm{gb}}\right)$ and non-polar desolvation energy $\left(\mathrm{G}_{\mathrm{surf}}\right)$. The value of the dielectric constant was set to 1 , and the external was set to 80 for solute protein ( $(\mathrm{in})$. The Generalized Born (GB) model established by Onufriev (GBOBC1) with modified Bondi radii (mbondi2) and igb $=2$ implemented in AMBER18 was used to calculate the electrostatic contribution to the solvation free energy. The non-polar surface area was calculated using the LCPO model. The offset $(\beta)$ and surface tension $(\gamma)$ values were set to $0.92 \mathrm{kcal} / \mathrm{mol}$ and $0.00542 \mathrm{kcal} /(\mathrm{mol} \cdot \mathrm{A} 2)$, respectively.

\section{Conclusions}

A number of novel $N 1-(\alpha, \beta$-alkene) substituted phenylpyrazolopyrimidine (PhPP) derivatives with acetyl and functionalized phenyl groups at $\alpha$ - and $\beta$-positions were synthesized, and they showed modest inhibitory activity $\left(\mathrm{IC}_{50}=21.7-192.1 \mu \mathrm{M}\right)$ against c-Src kinases. A number of para-chlorophenyl substituted compounds, 10 and 11, consistently inhibited the cell proliferation $72-96 \mathrm{~h}$ in all cell lines and were more effective against HT-29 cells. Compound $\mathbf{1 0}$ was also found to be modestly active against c-Src, Lck, and Btk. The target-based study of these compounds was performed by text mining, similarity search, and ligand-protein interaction pattern to identify potential targets. Further MD simulation and binding free energy calculations were carried out to discriminate the selectivity of the investigated compound with a panel of different kinases and provide more in-depth structural insight into the interaction pattern involved in the inhibition process. The structural and energetic features highlighted in this study can provide a theoretical basis for further research on selective protein kinase inhibitors.

Author Contributions: Methodology: B.S.C., N.S.J., S.A., S.M., and R.K.T.; writing-original draft preparation: B.S.C., Z.U.-H, and K.P.; supervision: Z.U.-H. and K.P.; funding acquisition: K.P.; performed the synthesis: B.S.C. and N.S.J.; conducted the antiproliferative assays: S.M. and D.M.; performed the kinase assays: R.K.T.; performed molecular modeling: S.A.; supervised, wrote, and edited the manuscript: Z.U.-H. and K.P. All authors contributed to writing the manuscript, editing, and reviewing of the manuscript. All authors read and agreed to the published version of the manuscript.

Funding: This research was funded by the American Cancer Society Grant \# RSG-07-290-01-CDD.

Acknowledgments: We acknowledge the financial support from the American Cancer Society Grant \# RSG-07-290-01-CDD and Chapman University School of Pharmacy.

Conflicts of Interest: The authors declare no conflicts of interest.

\section{References}

1. Yeatman, T.J. A renaissance for SRC. Nat. Rev. Cancer 2004, 4, 470-480. [CrossRef] [PubMed]

2. Summy JM, G.G. Src family kinases in tumor progression and metastasis. Cancer Metastasis Rev. 2003, 22, 337-358. [CrossRef] [PubMed] 
3. Irby, R.B.; Yeatman, T.J. Role of Src expression and activation in human cancer. Oncogene 2000, 19, 5636-5642. [CrossRef] [PubMed]

4. Jiao, Q.; Bi, L.; Ren, Y.; Song, S.; Wang, Q.; Wang, Y.S. Advances in studies of tyrosine kinase inhibitors and their acquired resistance. Mol. Cancer 2018, 17, 36. [CrossRef] [PubMed]

5. Wagner, J.; Von Matt, P.; Sedrani, R.; Albert, R.; Cooke, N.; Ehrhardt, C.; Geiser, M.; Rummel, G.; Stark, W.; Strauss, A.; et al. Discovery of 3-(1H-indol-3-yl)-4-[2-(4-methylpiperazin-1-yl)quinazolin-4yl]-pyrrole-2,5-dione (AEB071), a potent and selective inhibitor of protein kinase C isotypes. J. Med. Chem. 2009, 52, 6193-6196. [CrossRef]

6. Tsou, H.R.; Overbeek-Klumpers, E.G.; Hallett, W.A.; Reich, M.F.; Floyd, M.B.; Johnson, B.D.; Michalak, R.S.; Nilakantan, R.; Discafani, C.; Golas, J.; et al. Optimization of 6,7-disubstituted-4-(arylamino)quinoline3-carbonitriles as orally active, irreversible inhibitors of human epidermal growth factor receptor-2 kinase activity. J. Med. Chem. 2005, 48, 1107-1131. [CrossRef] [PubMed]

7. Schenone, S.; Radi, M.; Musumeci, F.; Brullo, C.; Botta, M. Biologically driven synthesis of pyrazolo [3, 4-d] pyrimidines as protein kinase inhibitors: An old scaffold as a new tool for medicinal chemistry and chemical biology studies. Chem. Rev. 2014, 114, 7189-7238. [CrossRef]

8. Kumar, A.; Ahmad, I.; Chhikara, B.S.; Tiwari, R.; Mandal, D.; Parang, K. Synthesis of 3-phenylpyrazolopyrimidine-1,2,3-triazole conjugates and evaluation of their Src kinase inhibitory and anticancer activities. Bioorg. Med. Chem. Lett. 2011, 21, 1342-1346. [CrossRef]

9. Mukaiyama, H.; Nishimura, T.; Kobayashi, S.; Ozawa, T.; Kamada, N.; Komatsu, Y.; Kikuchi, S.; Oonota, H.; Kusama, H. Synthesis and c-Src inhibitory activity of imidazo[1,5-a]pyrazine derivatives as an agent for treatment of acute ischemic stroke. Bioorg. Med. Chem. 2007, 15, 868-885. [CrossRef]

10. Trush, V.; Cherenok, S.; Tanchuk, V.; Kalchenko, V.; Vovk, A. Evaluation of inhibition of protein tyrosine phosphatase 1B by calixarene-based $\alpha$-ketophosphonic acids. Chem. Biol. Lett. 2015, 2, 1-5.

11. Rao, V.K.; Chhikara, B.S.; Tiwari, R.; Shirazi, A.N.; Parang, K.; Kumar, A. One-pot regioselective synthesis of tetrahydroindazolones and evaluation of their antiproliferative and Src kinase inhibitory activities. Bioorg. Med. Chem. Lett. 2012, 22, 410-414. [CrossRef] [PubMed]

12. Rao, M.S.; Chhikara, B.S.; Tiwari, R.; Shirazi, A.N.; Parang, K.; Kumar, A. Microwave-assisted and scandium triflate catalyzed synthesis of tetrahydrobenzo[a]xanthen-11-ones. Monatshefte fur Chemie 2012, 143, 263-268. [CrossRef]

13. Rao, V.K.; Chhikara, B.S.; Shirazi, A.N.; Tiwari, R.; Parang, K.; Kumar, A. 3-substitued indoles: One-pot synthesis and evaluation of anticancer and Src kinase inhibitory activities. Bioorg. Med. Chem. Lett. 2011, 21, 3511-3514. [CrossRef] [PubMed]

14. Nam, N.H.; Lee, S.; Ye, G.; Sun, G.; Parang, K. ATP-phosphopeptide conjugates as inhibitors of Src tyrosine kinases. Bioorg. Med. Chem. 2004, 12, 5753-5766. [CrossRef]

15. Deininger, M.; Buchdunger, E.; Druker, B.J. The development of imatinib as a therapeutic agent for chronic myeloid leukemia. Blood 2005, 105, 2640-2653. [CrossRef]

16. Shah, N.P.; Tran, C.; Lee, F.Y.; Chen, P.; Norris, D.; Sawyers, C.L. Overriding imatinib resistance with a novel ABL kinase inhibitor. Science 2004, 305, 399-401. [CrossRef]

17. Vultur, A.; Buettner, R.; Kowolik, C.; Liang, W.; Smith, D.; Boschelli, F.; Jove, R. SKI-606 (bosutinib), a novel Src kinase inhibitor, suppresses migration and invasion of human breast cancer cells. Mol. Cancer Ther. 2008, 7, 1185-1194. [CrossRef]

18. Martina Ferrari, S.; La Motta, C.; Sartini, S.; Baldini, E.; Materazzi, G.; Politti, U.; Ruffilli, I.; Ulisse, S.; Miccoli, P.; Antonelli, A. Pyrazolopyrimidine derivatives as antineoplastic agents: With a special focus on thyroid cancer. Mini Rev. Med. Chem. 2016, 16, 86-93. [CrossRef]

19. Crisci, S.; Di Francia, R.; Amitrano, F.; Saggese, M.; Mele, S.; Ronga, G.; De Filippi, R.; Berretta, M.; Rossi, P.; Pinto, A. Overview of Targeted Drugs for Mature B-Cell Non-hodgkin Lymphomas. Front. Oncol. 2019, 9, 443. [CrossRef]

20. Akinleye, A.; Chen, Y.; Mukhi, N.; Song, Y.; Liu, D. Ibrutinib and novel BTK inhibitors in clinical development. J. Hematol. Oncol. 2013, 6, 59. [CrossRef]

21. Xu, W.; Doshi, A.; Lei, M.; Eck, M.J.; Harrison, S.C. Crystal Structures of c-Src Reveal Features of Its Autoinhibitory Mechanism. Mol. Cell 1999, 3, 629-638. [CrossRef] 
22. Zhu, X.; Kim, J.L.; Newcomb, J.R.; Rose, P.E.; Stover, D.R.; Toledo, L.M.; Zhao, H.; Morgenstern, K.A. Structural analysis of the lymphocyte-specific kinase Lck in complex with non-selective and Src family selective kinase inhibitors. Structure 1999, 7, 651-661. [CrossRef]

23. Bookser, B.C.; Ugarkar, B.G.; Matelich, M.C.; Lemus, R.H.; Allan, M.; Tsuchiya, M.; Nakane, M.; Nagahisa, A.; Wiesner, J.B.; Erion, M.D. Adenosine Kinase Inhibitors. 6. Synthesis, Water Solubility, and Antinociceptive Activity of 5-Phenyl-7-(5-deoxy- $\beta$-d-ribofuranosyl)pyrrolo[2,3-d]pyrimidines Substituted at C4 with Glycinamides and Related Compounds. J. Med. Chem. 2005, 48, 7808-7820. [CrossRef] [PubMed]

24. Chhikara, B.S.; Parang, K. Development of cytarabine prodrugs and delivery systems for leukemia treatment. Expert Opin. Drug Deliv. 2010, 7, 1399-1414. [CrossRef] [PubMed]

25. Chhikara, B.S.; Mandal, D.; Parang, K. Synthesis and evaluation of fatty acyl ester derivatives of cytarabine as anti-leukemia agents. Eur. J. Med. Chem. 2010, 45, 4601-4608. [CrossRef]

26. Chhikara, B.S.; Rathi, B.; Parang, K. Critical evaluation of pharmaceutical rational design of nano-delivery systems for doxorubicin in cancer therapy. J. Mater. Nanosci. 2019, 6, 47-66.

27. Nasrolahi Shirazi, A.; Tiwari, R.; Chhikara, B.S.; Mandal, D.; Parang, K. Design and biological evaluation of cell-penetrating peptide-doxorubicin conjugates as prodrugs. Mol. Pharm. 2013, 10, 488-499. [CrossRef]

28. Chhikara, B.S.; St. Jean, N.; Mandal, D.; Kumar, A.; Parang, K. Fatty acyl amide derivatives of doxorubicin: Synthesis and in vitro anticancer activities. Eur. J. Med. Chem. 2011, 46, 2037-2042. [CrossRef]

29. Chhikara, B.S.; Mandal, D.; Parang, K. Synthesis, anticancer activities, and cellular uptake studies of lipophilic derivatives of doxorubicin succinate. J. Med. Chem. 2012, 55, 1500-1510. [CrossRef]

30. Behera, D.K.; Behera, P.M.; Acharya, L.; Dixit, A. Development and validation of pharmacophore and QSAR models for influenza PB2 inhibitors. Chem. Biol. Lett. 2017, 4, 1-8.

31. Sharma, D.; Pathak, M.; Sharma, R.; Sharma, N.; Tyagi, P.; Chawla, R.; Basu, M.; Ojha, H. Homology modeling and docking studies of VP24 protein of Ebola virus with an antiviral drug and its derivatives. Chem. Biol. Lett. 2017, 4, 27-32.

32. Kanehisa, M.; Shlomi, T.; Ruppin, E.; Koonin, E.; Snoddy, J.; Gerstein, M.; Sheffer, M.; Alon, U. KEGG: Kyoto Encyclopedia of Genes and Genomes. Nucl. Acid. Res. 2000, 28, 27-30. [CrossRef] [PubMed]

33. Wang, Z.; Liang, L.; Yin, Z.; Lin, J. Improving chemical similarity ensemble approach in target prediction. J. Cheminform. 2016, 8, 20. [CrossRef] [PubMed]

34. Roth, A.; Franceschini, A.; Szklarczyk, D.; Heller, D.; Simonovic, M.; Wyder, S.; von Mering, C.; Huerta-Cepas, J.; Forslund, K.; Bork, P.; et al. STRING v10: Protein-protein interaction networks, integrated over the tree of life. Nucl. Acid. Res. 2014, 43, D447-D452.

35. Szklarczyk, D.; Santos, A.; Von Mering, C.; Jensen, L.J.; Bork, P.; Kuhn, M. STITCH 5: Augmenting protein-chemical interaction networks with tissue and affinity data. Nucl. Acid. Res. 2016, 44, D380-D384. [CrossRef] [PubMed]

36. Chandel, V.; Raj, S.; Rathi, B.; Kumar, D. In silico identification of potent FDA approved drugs against Coronavirus COVID-19 main protease: A drug repurposing approach. Chem. Biol. Lett. 2020, 7, 166-175.

37. Wencheng, X.; Zhang, L.; Yin, Y.; Yang, D.; Zhao, G. 3D-QSAR and molecular docking studies of ATP-competitive Akt inhibitors with the scaffold 4-(piperazin-1-yl)pyrimidine. Chem. Biol. Lett. 2014, 1, 44-54.

38. Kollman, P.A.; Massova, I.; Reyes, C.; Kuhn, B.; Huo, S.; Chong, L.; Lee, M.; Lee, T.; Duan, Y.; Wang, W.; et al. Calculating structures and free energies of complex molecules: Combining molecular mechanics and continuum models. Acc. Chem. Res. 2000, 33, 889-897. [CrossRef]

39. Chandel, V.; Srivastava, M.; Srivastava, A.; Asthana, S.; Kumar, D. In-silico interactions of active Phytochemicals with c-MYC EGFR and ERBB2 oncoproteins. Chem. Biol. Lett. 2020, 7, 47-54.

40. Case, D.A.; Cheatham, T.E.; Darden, T.; Gohlke, H.; Luo, R.; Merz, K.M.; Onufriev, A.; Simmerling, C.; Wang, B.; Woods, R.J. The Amber biomolecular simulation programs. J. Comput. Chem. 2005, 26, 1668-1688. [CrossRef]

41. Wang, J.; Wolf, R.M.; Caldwell, J.W.; Kollman, P.A.; Case, D.A. Development and testing of a general Amber force field. J. Comput. Chem. 2004, 25, 1157-1174. [CrossRef] [PubMed]

42. Maier, J.A.; Martinez, C.; Kasavajhala, K.; Wickstrom, L.; Hauser, K.E.; Simmerling, C. ff14SB: Improving the Accuracy of Protein Side Chain and Backbone Parameters from ff99SB. J. Chem. Theor. Comput. 2015, 11, 3696-3713. [CrossRef] [PubMed] 
43. Darden, T.; York, D.; Pedersen, L. Particle mesh Ewald: An N·log(N) method for Ewald sums in large systems. J. Chem. Phys. 1993, 98, 10089-10092. [CrossRef]

44. Ryckaert, J.C.; Ciccotti, G.; Berendsen, H.J.C. Numerical Integration of the Cartesian Equations of Motion of a System with Constraints. J. Comp. Phys. 1977, 23, 327-341. [CrossRef]

Sample Availability: Samples of the limited number the compounds are available from the authors upon request.

(C) 2020 by the authors. Licensee MDPI, Basel, Switzerland. This article is an open access article distributed under the terms and conditions of the Creative Commons Attribution (CC BY) license (http://creativecommons.org/licenses/by/4.0/). 